Historic, Archive Document

Do not assume content reflects current scientific knowledge, policies, or practices. 



\section{QUALITY NURSERY STOCK}

\section{THE FREMONT NURSERY}

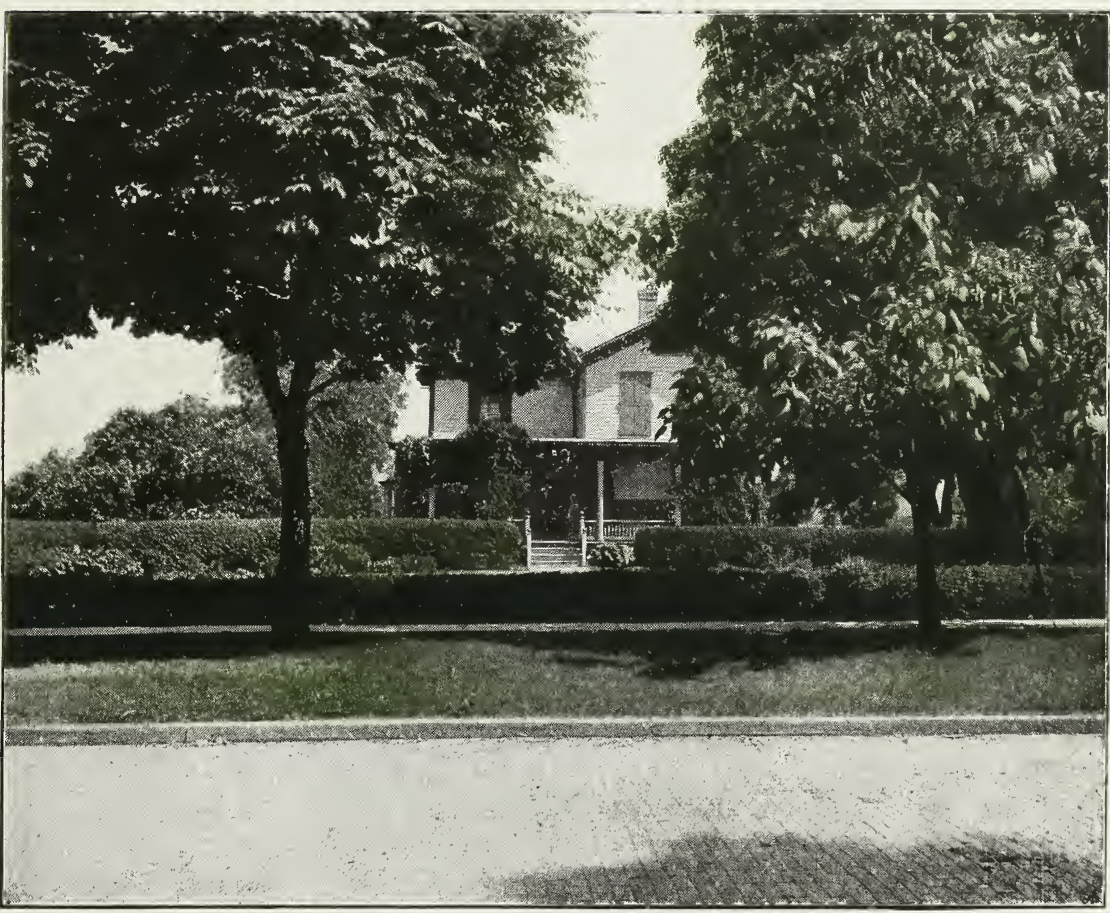

Old Fomestead at the Fremont Nursery

Fruit and Ornamental Trees, Vines, Shrubs, Berry Plants, Etc.

\section{The Fremont Nursery}

Established 1858 - Branch at Geneva, N. Y.

Fremont, :: :: :: :: Ohio 


\section{INTRODUCTION}

The Fremont Nursery was established in its present location in 1858. Starting from small beginnings we have enjoyed a prosperous and steady growth from rear to year. This growth has not been due to bombastic advertisements and impossible promises. It has been due to our manner of doing business and the quality and reliability of our stock. Hundreds of satisfied customers have done our advertising for us, and this has been especially true in several of the large fruit growing sections. We have many large fruit growers among our customers who have been dealing with us almost yearly for fifteen, twenty and twenty-five years.

We make it a rule to look out for our customers' interest as well as our own. We never recommend a variety of fruit simply to obtain an exhorbitant price for it, or dispose of a surplus of trees of that variety. We gladly advise our customers honestly to the best of our ability regardless of the condition of our stock.

We go slow on new and untried varieties, yet we are constantly testing and investigating them, keeping those which show merit and throwing out those which are found wanting.

We obtain new starts from buds and scions from bearing trees, always selecting those which produce the finest fruit, every few years, and thus avoid any possible chance of a mixture of varieties. This practice is responsible for the remarkable reliability of our stock for the nearly sixty years of our existence.

We have our own peach orchard of about 1300 trees in which we have about 50 varieties from which to renew our start in buds whenever we desire.

All buds and scions are cut by the proprietor himself, one who has grown up in the nursery business and who is constantly laboring among his trees and shrubs and who knows perfectly all the characteristics of the different varieties in the nursery row.

We have a great variation of soil ranging from rich sandy loam to a heavy black loam which enables us to grow a great variety of stock. We do not claim to have the largest nursery in the country. And we do not desire to have, but we do claim to have one of the best, and as large a one as it is practicable to have and at the same time give our personal supervision thereto. In the nursery business more than in any other line it is possible to have so much to do that it can't be done well. A little neglect at the right time may injure an entire block of trees or ruin an en. tire shipment.

We know that thousands of mistakes are made and thousands of trees spoiled every year by the trusting of important branches of the business to careless and incompetent help. Incidentally we might mention that we grow every year for both the wholesale and retail trade several hundred thousand trees.

It is our ambition to serve our customers and look after their interest ahead of our own and give them the best value for their money.

PRICES-Our prices are as low as it is possible to grow stock of good quality for. We do not claim to sell cheaper than anyone else, but do claim that considering the quality of the stock and the personal care and supervision given in the growing and handling of the same, thus insuring stock true to name and in good condition, that our stock is as cheap as any, if not cheaper in the end.

INSPECTION-Our nursery is inspected every year by the State Officials; original certificate of inspection is on file at the nursery and copies are placed on all shipments.

CARE - We exercise the greatest care in the digging and handling of our stock and guarantee all shipments to reach destination in good condition.

A new frost proof storage cellar, $100 \times 70 \mathrm{ft}$., gives us largely increased facilities for the storing of tender trees in the Winter and the early handling in the Spring.

ERRORS - Should be reported immediately on receipt of goods. And if so done, all errors on our part will be cheerfully rectified. Order early and insure getting the varieties wanted, but always state whether, in case we should be out of any variety wanted, we should use a similar and equally as good a variety ripening at the same time or omit.

SHIPPING SEASON -Usually begins about April first. and continues into May, depending upon the weather. Fall season usually begins about October 15 th and continues till ground freezes.

NOMENCLATURE-In this catalogue we have endeavored to conform to the revised, simplified and improved form of names of varieties as adopted by the American Pomological Society and indorsed by the Ohio and other Horticultural Societies.

INFORMATION - We are always glad to help you in the planning of your orchard, the selection of your varieties, or the planning and planting of your yard for ornamental purposes. Be free to call upon us.

PREPARING THE SOIL-Fruit trees flourish best in a naturally dry soil; too much moisture retards growth. Plow at least twice, following the common plow the second time with the subsoil plow. Fresh lands will not need manure or fertilizers but land exhausted through constant cropping should be fertilized either by turning under clover or well decomposed manure or compost. Land that is in good condition for wheat, corn or potatoes will be well adapted to fruit trees.

PLANTING-Dig the hole larger than is necessary to admit all the roots in their natural position,, keeping the surface soil and subsoil separate. Have the trees held in an upright position while the earth is shoveled in, the best soil being sifted in among the roots. Make sure that all the roots come in contact with the soil. When the earth is nearly filled in, pour in water to wash the soil around the roots; then fill up the remainder and tread down gently with the foot. It is only necessary to use water in dry weather.

Don't plant too deep; the trees should stand about the way they did in the nursery. Trees on dwarf stock should be planted so that all the stock is below the ground, only the graft appearing above the surface.

STAKING - Extra tall trees or those much exposed to the wind should be supported by a stake. Take care that no chafing of the tender bark occurs.

PRUNING-Both root and top should be pruned at time of planting and before the tree is set in the ground. First cut off the ends of the broken and bruised roots with a sharp knife, in a slanting direction on the under side. This will cause the wound to heal over readily, by throwing out plenty of fibrous roots at the end. Then cut back each branch or side limb to a bud not more than four or five inches from the body. Then cut back the leader or central limb so as to leave it about four or five inches above the highest side limb. When there are no side limbs the tree should be headed back to a height proper to form a top. None of the lower limbs should be cut off entirely, as it is best to form the heads as low as possible, so that the limbs and leaves will protect the trunk from the direct rays of the sun. 


\section{APPLES, THE KING OF FRUITS}

The apple is universally recognized as the most desirable fruit of the United States, because of its great varieties of delicious flavors, nutritious qualities and nutrative value. Whether as commercial crop or for the satisfaction of the family, a well selected orchard of a few varieties is a most desirable investment that any land owner can place on his premises.

We recommend the planting of a few thrifty trees from one to three years old and from four to five feet high as such are more safely handled than older and larger trees.

\section{SUMMER APPLES}

EARLY HARVEST-Medium to large; roundish, pale yellow; flesh white, tender, juicy, crisp, with a rich sub-acid flavor; fine. Tree moderate grower, erect; very productive. Middle of August. One of the very best early varieties.

GOLDEN. SWEET-Large, pale yellow; very sweet and productive. Tree strong branching grower. August and September.

RED ASTRACHAN-Large; roundish; nearly covered with deep crimson, overspread with a thick bloom; very handsome; juicy, good, rather acid. Tree of the hardiest, vigorous and a good bearer. August.

SWEET BOUGH (Large Yellow Bough)-Large; pale yellow; very tender, crisp, juicy, sweet, fine. Tree a moderate grower, good bearer, but not as prolific as Golden Sweet, but of finer quality. August.

YELLOW TRANSPARENT-A Russian apple. The tree is hardy as the crab, a good upright grower; a very abundant, regular and early bearer; the fruit full medium size; color a rich, transparent lemon-yellow, with a faint flush on sunny side; flesh melting, juicy, pleasant, subacid. A few days earlier than the Early Har. vest and is the earliest ripening apple known.

\section{AUTUMN APPLES}

FAMEUSE (Snow Apple)-Medium, roundish; deep crimson. Very handsome; flesh snowy white, tender, melting, juicy, high flavored, subacid, delicious. Tree moderate grower, very hardy and productive. November to January.
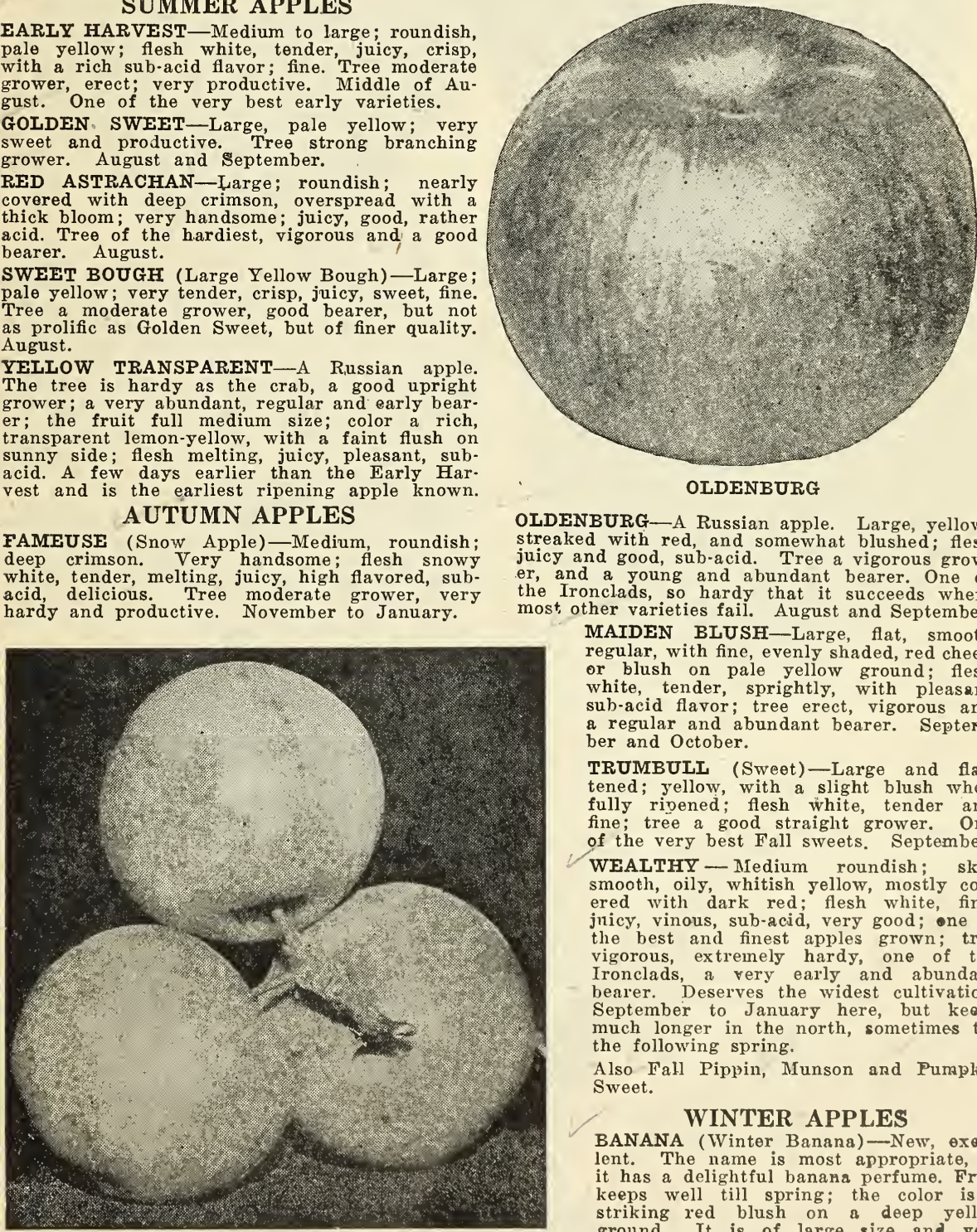

OLDENBURG-A Russian apple. Large, yellow, streaked with red, and somewhat blushed; flesh juicy and good, sub-acid. Tree a vigorous grower, and a young and abundant bearer. One of the Ironclads, so hardy that it succeeds where most, other varieties fail. August and September. MAIDEN BLUSH-Large, flat, smooth regular, with fine, evenly shaded, red cheek or blush on pale yellow ground; flesh white, tender, sprightly, with pleasant sub-acid flavor; tree erect, vigorous and a regular and abundant bearer. September and October.

TRUMBULL (Sweet)-Large and flattened; yellow, with a slight blush when fully ripened; flesh white, tender and fine; tree a good straight grower. One of the very best Fall sweets. September.

WEALTHY - Medium roundish; skin smooth, oily, whitish yellow, mostly covered with dark red; flesh white, fine, jnicy, vinous, sub-acid, very good; one of the best and finest apples grown; tree vigorous, extremely hardy, one of the Ironclads, a very early and abundant bearer. Deserves the widest cultivation. September to January here, but keops much longer in the north, sometimes till the following spring.

Also Fall Pippin, Munson and Pumpkin Sweet.

\section{WINTER APPLES}

BANANA (Winter Banana)-New, exeellent. The name is most appropriate, as it has a delightful banana perfume. Fruit keeps well till spring; the color is a striking red blush on a deep yellow ground. It is of large size an very showy in appearance, roundish, inclining to conical; stalks three-fourths of an ineb 


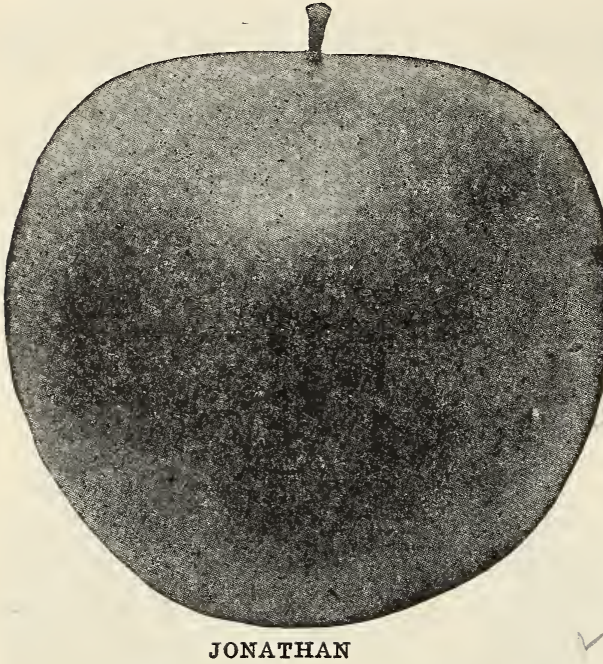

long, cavity moderate, apex shallow. Originated in Indiana.

BALDWIN-Large, roundish; skin deep red, flesh juicy; crisp, sub-acid; good flavor; tree very vigorous, upright and productive; one of the most popular and profitable winter varieties. December to March.

BEN DAVIS-Large, handsome, striped, and of fair quality; mild, sub-acid. Treo very hardy, a vigorous grower, constant, abundant bearer; highly esteemed as one of the most profitable market sorts. December to March.

BLACK BEN (Reagan's Red)-Improved Ben Davis. Said to be a much more hadadsome apple, being a solid dark red color, and of better qual. ity, succeeding everywhere and keeping as long as Ben Davis.

DELICIOUS-Claimed by the introducers to be "the best apple in the world.", They claim for it, good size, beautiful dark red color, and incomparable in flavor. Nearly sweet with a very slight touch of acid and very aromatic. A long keeper. A strong, hardy tree and a sure bearer. One of the most popular market sorts.

DOMINE-A large, flattened, greenish yellow apple, with stripes of bright red; flesh white, tender and juicy; good grower and very productive. Fine; also called Winter Rambo. November to April.

FALLAWATER (Tulpehoeken Pound etc) - A very large, round; yellowish green with dull red cheeks; tender and juicy, crisp, pleasant, peculiar sub-acid flavor; tree a vigorous grower, very productive even while young. Nov. to March. GANO-Originated in Missouri. Form conical, good size and smooth; deep red shaded on sunny side to mahogany; very attractive; flesh pale yellow, fine grained, tender, pleasant, mild, subacid; is a good shipper and keeper; tree healthy vigorous and hardy. An annual and prilific bearer called an improved Ben Davis, and by many leading horticulturists said to be identical with Black Ben Davis.

HUBBARDSON-Large, round; beautiful yellow, striped and splashed with red; flesh tender. juicy and fine, with agreeable rich flavor hard to distinguish between sweetness and acidity; tree vigorous; bears large crops. November to January.

JONATHAN-Medium size; red and yellow; flesh tender, juicy and rich; a moderato grower; shoots light-colored, slonder and spreading; very productive. One of the best varieties for either table or market. November to March.
M'INTOSF-Origin, Ontario. Season December and January. A choice variety of the Fameuse type. Tree vigorous with spreading head; a good annual bearer. Fruit above medium to large, highly perfumed; smooth polished yellow, almost covered with brilliant solid crimson, a beautiful fruit; flesh snow white, crisp, very tender, sprightly aromatic, sub-acid, good quality. MANN-Originated in Niagara county, N. Y. Medium to large, roundish, oblate; deep yellow, often with a shade of brownish red where exposed; flesh yellowish, juicy, mild, pleasant. subacid. Tree hardy, an upright, vigorous grow(l). Fruit keeps firm till late in the spring, and matures after Greening is gone. Very valuable as a cooking and eating apple for spring use. January to May.

NORTHERN SPY-Large, roundish, slightly conical, somewhat ribbed; quite covered on the sunny side with dark crimson, and having a pale bloom; flesh white, tender, juicy, spicy, high flavored and delicious, sub-acid; retaining freshness of appearance and flavor until June. Tree is a remarkably vigorous erect grower, and a great bearer. Requires thinning of the head to admit light and air freely to the fruit. Both leaf and blossom buds open a week later than other varieties. January to June.

NORTHWESTERN (Greening)-New, originated in Waupaca county, Wis. Fruit medium to large, averaging from seven to eight ounces each and very uniform in size. Color greenish yellow, fiesh juicy, firm and fine grained, veŕy fine quality and flavor. Tree is very hardy and a thrifty grower, an early and continuous bearer; one of the longest keepers known. January to June.

RAMBO-Medium size; streaked and mottled yellow and red; very tender, juicy, sprightly and fine flavored; tree vigorous and good bearer. Fall apple in south. October to January in the north. Have kept this apple till March many times in an ordinary cellar.

RHODE ISLAND GREENING-Large, roundish green or greenish yellow; tender, juicy and rich; rather acid, but high flavored and one of the best for cooking and dessert; tree vigorous, spreading, very crooked grower in the nursery; a great and constant bearer nearly everywhere. Toward the south ripens in the fall, but in the north a late keeper. Decenber to April.

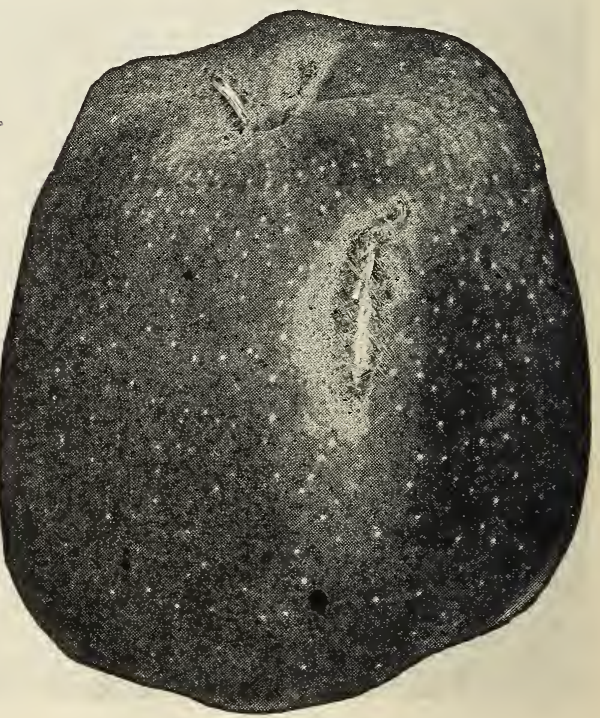

DELICIOUS 


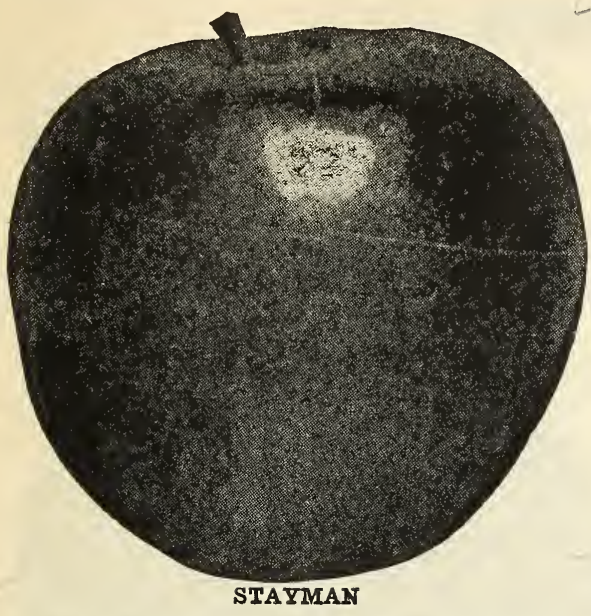

ROME BEAUTY-Large; yellow and bright red; flesh yellowish, tender, juicy, sub-acid; tree moderate grower, good bearer. December to March. STARK-Large, roundish, greenish yellow shaded, sprinkled and striped with light and dark red nearly over the whole surface, and thickly sprinkled with light brown dots; flesh yellowish, moderately juicy, mild, sub-acid; tree vigorous, an early and abundant bearer, hardy; the fruit a long keeper and valuable market fruit. January to April.

STAYMAN-Kansas origin. Oblate conical, medium large; green, yellow and red striped; flesh yellow, fine, tender, juicy, rich, mild, acid; very good to best; valuable for dessert and market. Season very late.

SUTTON-Medium to large, roundish; handsome waxen yellow, shaded mottled, and obscure. ly striped with fine crimson; flesh whitish, crisp, tender, juicy, sprightly sub-acid; quality fine; late keeper; tree a vigorous, handsome grower and productive. One of the most valuable market varieties. November to Februa" "v.
TOLMAN (Tolman's Sweet)-Medium size; pale yellow, slightly tinged with red; firm, rich and sweet; excellent for cooking; tree vigorous, very hardy and productive. November to April.

TOMPKIN'S KING-Largest size, oblate, yellowish ground striped and covered with bright red; fragrant, spicy sinelling; flesh very crisp, tender, rich, fine flavor.

WAGENER-Medium to large; light yellow covered with deep red in the sun; firm, crisp, juicy, sub-acid; tree vigorous, upright, handsome, very productive. December to May.

YORK IMPERIAI-Medium; white shaded with crimson; flesh firm, crisp, juicy, pleasant, mild, sub-acid; tree vigorous, a good bearer. A pop. ular Pennsylvania variety. November to Feb.

Also Arkansas Black, Golden Russet, King David, Chenango, Greenville, Opalescent, Pewaukee, Roxbury, Salome, Esopus (Spitzenburg), Westfield (Seek-no-Further), Winesap, Wolf Ri-' ver, Yellow Newtown, Yellow Belleflower, etc.

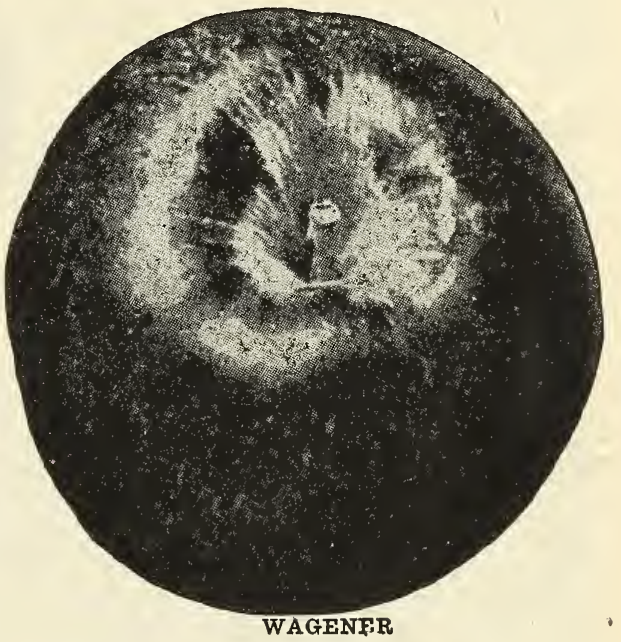
as:

\section{- CRAB APPLES}

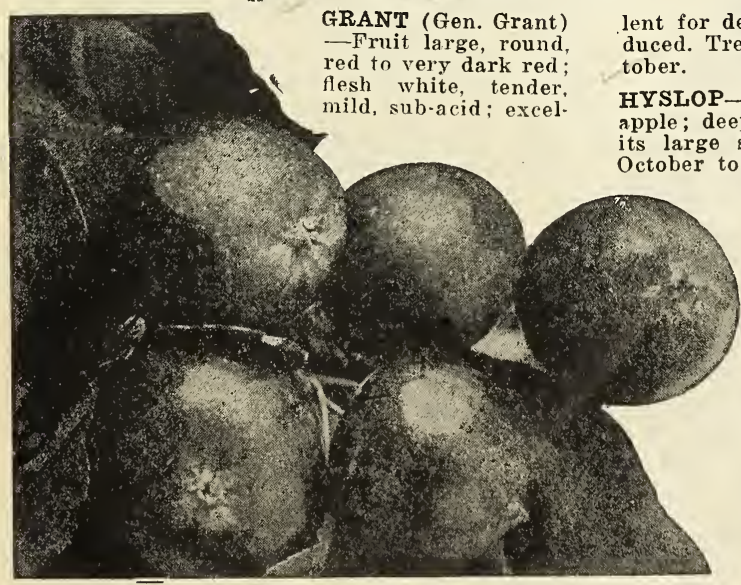

TRANSCENDENT CRAB lent for dessert, and one of the best crabs introduced. Tree a vigorous and upright grower. Oc. tober.

HYSLOP-Almost as large as Early Strawberry apple; deep crimson; very popular on account of its large size, beauty and hardiness. Vigorous. October to January.

TRANSCENDENT - Skin yellow, triped wich red; flesh crisp and juicy. An early and heavy bearer. One of the best known varieties. Vigorous. September and Oc. tober.

WHITNEY-Large, glossy green, striped, splashed with carmine; flesh firm, juicy and flavor very pleasant; ripe latter part of $\mathrm{Au}$ gust. Tree a great bearer and very hardy; a vigorous, handsome grower and very hardy; a vigorous, handsome grower, with a dark green, glossy foliage. Vigorous. August.

Crab apples are especially de. sirable in the colder sections as only a few varieties of apples oan be successfully grown. 


\section{PEARS}

The pear succeeds on most soils, but does best on a rather heavy loam Budded on its own stock it makes what is called a Standard tree; but on Quince stock it makes Dwarf. Standards are best adapted to large, permanent orchards; but dwarfs will come into bearing very much sooner and may be planted much closer together. Dwarf must always be planted sufficiently deep to cover the quince stock two or three inches.

\section{SUMMER PEARS}

BARTLETT-Large size, with often a beautiful blush next the sun; buttery, very juicy and high flavored; bears early and abundantly; very popular. Vigorous. August and September.

CLAPP'S FAVORITE-Very large; yellowish green to full yellow when ripe, marbled with dull red in the sun and covered with small russet specks; vinous, melting and rich. Should be gathered early. Vigorous. August.

EARLY WILDER-Medium, or rather small, regular in form; greenish yellow with a brownish red cheek; handsome, melting, sweet, pleasant, very good; tree a vigorous grower and great bearer. First of August.

\section{AUTUMN PEARS}

ANJOU-Large, greenish, sprinkled with russet, sometimes shaded with dull crimson; flesh whitish, buttery, melting, with a high, rich, vinous excellent flavor; very productive; succeeds well on the quince; should be in every orchard. Vigorous. October to December.

ANGOULEME (Duchess) - Very large, dull greenish yellow, streaked and spotted with rus. set; flesh white, buttery and very juicy with a rich and very excellent flavor. Vigorous. October and November.

CLAIRGEAU-Large; skin yellow, inclined to fawn, shaded with orange and crimson, covered with russet dots; flesh yellow, buttery, juicy, somewhat granular with a sugary, perfumed, vinous flavor. Moderate. October to December.

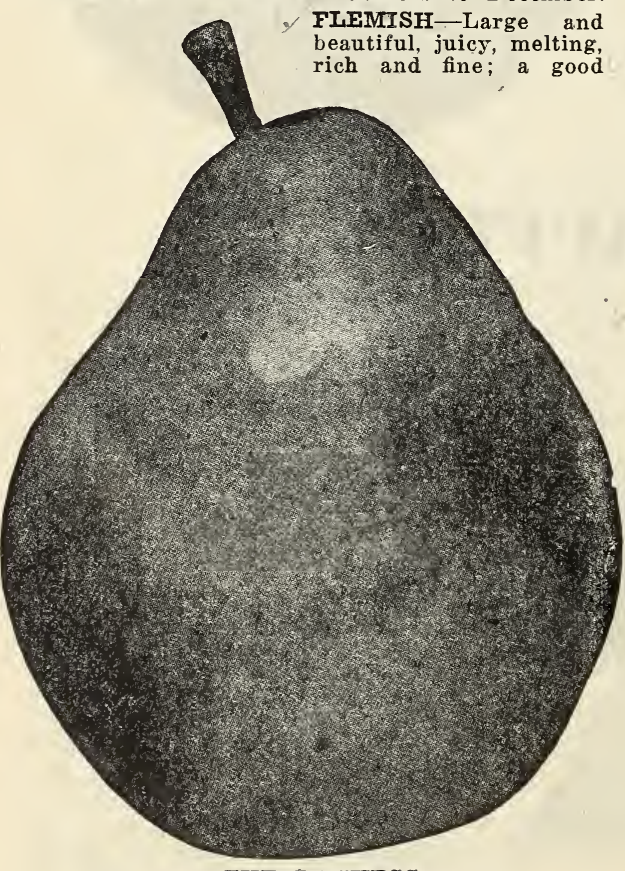

THE DUCHESS

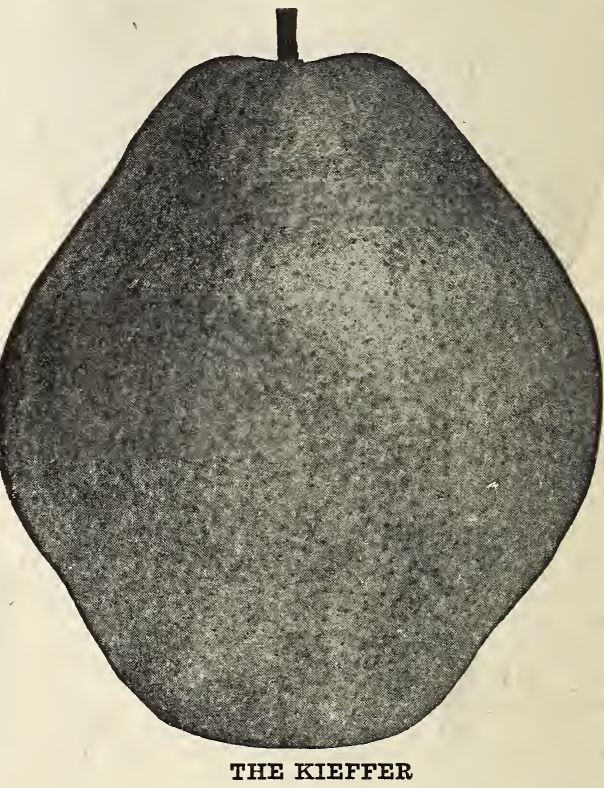

bearer; hardy everywhere. Vigorous. Septem. ber and October.

KIEFFER-Very large, bell shaped; light yellow when fully ripe, sometimes with a slight blush; flesh white, crisp, juicy, of slightly quince flavor; or fair quality; exceedingly valuable for cooking or canning, which brings out its best spicy flavor; never rots at core. The tree is an extraordinary vigorous grower, and must be severely pruned. It it is a wonderfully abundant and regular bearer, and the fruit must be thinned for the best results. Extremely vigorous. October to December.

LAWRENCE-Rather large; yellow, covered with brown dots; flesh whitish, slightly granular, somewhat buttery, with a very rich, aromatic flavor, unsurpassed among the early winter pears; succeeds well on the quince; ripens with little care; should be in every orchard; tree healthy, hardy and productive. Free grower. November to January.

SECKEL-Small; skin rich yellowish brown with a deep brownish red cheok; flesh very fine grained, sweet, exceedingly juicy, melting, buttery; the richest and highest flavored pear known. Moderate. September and October.

SHELDON - Large size; yellow or greenish russet, with a richly shaded cheek; flesh a little coarse, melting, juicy, a very brisk, vinous, highly perfumed flavor; productive; vigorous. Oct.

\section{DWARF PEARS}

As certain varieties of Pears are not successful when grown as Dwarfs, we herewith give a special list of such as are most suitable, and of which the Duchess d'Angouleme is decidedly the best of all: Anjou, Clapp's Favorite, Angouleme (Duchess), Kieffer, Louise, Lawrence and 'Seckel. 


\section{CHOICE PLUMS}

ABUNDANCE-One of the best Japan Plums. The tree is a very rapid grower, healthy in limb and foliage, comes into bearing remarkably young, and yields abundantly. The fruit is full medium size, color a rich cherry red, with a dis. tinct bloom, highly perfumed; flesh light yellow, very juicy and tender, and of excellent quality. Vigorous. Last of July.

ARCTIC (Moore's)-Fruit grows in large clusters; large, dark purple; flavor very fine both for preserving and dessert. Long keeper. Vig. orous. September.

BRADSHAW-Fruit very large, dark violet red; flesh yellowish green; juicy and pleasant; very productive. One of the most profitable for market. Comes at a good season, of fine appearance and brings a good price. Vigorous. Middle of August.

BURBANK-A valuable Japanese Plum, cherry red with a thin lilac bloom; flesh a deep yellow; very sweet, with a peculiar and very agreeable flavor. The tree is a vigorous grower. August.

FELLENBURG (Italian Prune)-Medium large; purplish-black; blue bloom; free; flesh greenish-yellow, juicy, sweet and of good quality; will hang on tree after ripening; splendid for drying and market. Tree very productive. September.

GEUII-Fruit very large, deep bluish purple, covered with thick bloom; flesh yellowish green; coarse, sweet and pleasant: great bearer and very early; tree a hardy and rapid grower. One of the most profitable for market. Vigorous. First to middle of September.

IMPERIAI GAGE-Fruit large, oval, skin pale green, flesh juicy, sweet, rich and excellent. Vigorous. Middle of August.

LOMBARD-Medium, roundish oval; violet red; juicy, pleasant and good; adheres to the stone productive. A valuable market variety; one of the most hardy and popular. Nearly always produces a crop. Not liable to rot. Vigorous. Middle of August.

RED JUNE-An early ripening Japanese Plum; medium to large, roundish, conical, purplish red; handsome; flesh yellow, quality good.

REINE CLAUDE-Large, nearly round; pale yellow, marked with red; juicy, melting and excellent, good bearer. Not liable to rot. One of the most profitable for market. Vigorous. First of September.

SHROPSHIRE-A Plum of fine quality, as free from the attacks of the Curculio as the Common Damson and of same color. The flesh is amber colored, juicy and sprightly. Very productive and of a valuable market variety. Not liable to rot. Free. September.

WICKSON-Very large, reddish-purple, with white bloom; cling; flesh firm and meaty; yellow, rich, aromatic; a market sort. Tree strong and spreading; bears abundantly and early, in most localities. August.

YELLOW EGG-Very large, egg-shaped; excellent for cooking; good and productive. Vigorous. Last of August.

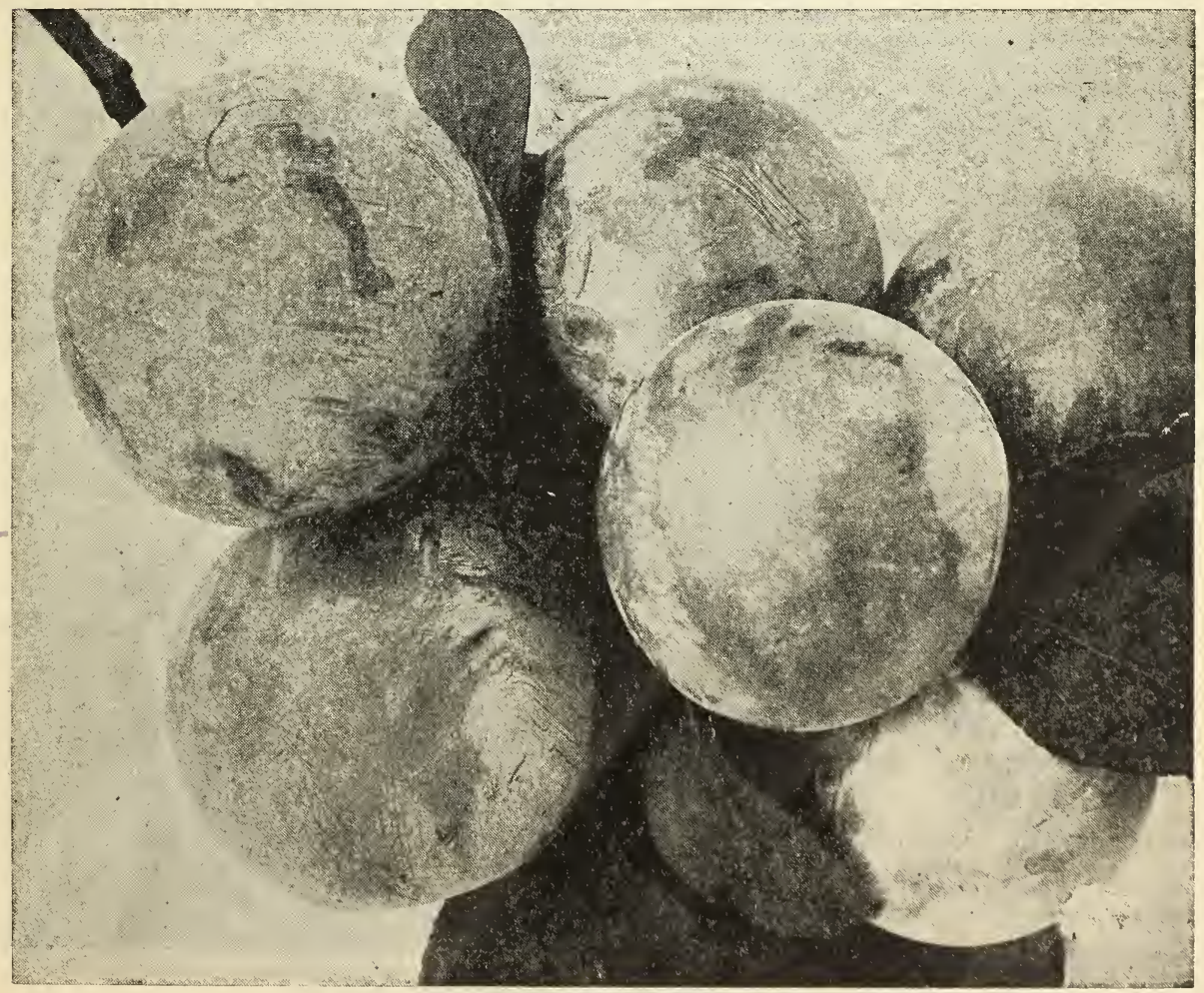




\section{CHERRIES OF QUALITY}

Mazzard root for Sweet Cherry. We are one of the few who can supply them. Do you remember years ago that the old time Sweet Cherry trees did so much better than they do now? Have you heard fruit growers wonder at it? Do you know the reason? It is because years ago the Sweet Cherry, in fact all cherry, were budded on Mazard roots. Then the Mahaleb root came into vogue and its use became general because it was so much easier to bud successfully than the Mazzard. And it proved to be a better stock for the sour varieties, but not so for the sweets. Yet it was adopted almost universally as a stock for the Cherry, both sweet and sour and that practice is in use today in almost all the nurseries of the country. A Sweet Cherry tree can be produced much cheaper on a Mahaleb root than on a Mazzard but it is not worth one-fourth ss much. We have made a practice to grow a limited number of Sweet Cherry on Mazzard roots each year for the benefit of our customers who wanted them. If you wish them you must specify Mazzard roots and send in your order early, and observe that we cannot furnish them at the same price as we ask for ordinary Sweet Cherries which are on Mahaleb roots.

The Cherry thrives best on a dry, sandy or gravelly soil, and there attains its highest perfection, but will do well in almost any situation except a wet one. We divide them into two classes: (1) Hearts and Bigarreaus; (2) Dukes and Morellos. The former are strong and vigorous growers, making large, open, spreading heads; their fruit is large, heart shaped, meaty and sweet. The Dukes and Morellos do not attain so large size, but are more hardy and less liable to injury from bursting the bark; their fruit is acid or sub-acid.

\section{HEART AND BIGARREAU CHERRIES}

BING-Originated in Oregon. The fruit is very large, dark brown turning to black when ripe and of the finest quality. One of largest and most delicious sweet cherries grown. Tree strong, stocky, thrifty grower with heavy foli. age. Should be followed by Lambert which ripens later.

LAMBERT-Another of the best sweet sorts, originating in Oregon. Dark purplish red turning to jet black when ripe. Extra large, flesh firm and rich. Tree a strong grower, hardy and very productive. A splendid sort to follow Bing.

NAPOLEON-Very large, pale yellow or red; very firm, juicy and sweet; very productive; one of the best. Vigorous. First of July.

SCHMIDT-Remarkably hardy and productive. Fruit grows in clusters and of the largest size; a deep black color; flesh dark, tender, juicy, with a fine rich flavor. Tree hardy. Vigorous. July. We consider this the best all around Black Sweet Cherry.

SPANISH-Large, pale yellow, with red cheek; firm, juicy and excellent; one of the best light colored cherries; productive. Free. Last of June.

TARTARIAN-Very large, bright purplish black; half tender, juicy, very rich, excellent flavor; productive. Free. First to middle of July.

WINDSOR-Fruit large; liver colored, resembling the Elkhorn, ripening a few days after that variety; flesh remarkably firm, of fine quality. Tree hardy and prolific. Vigorous. Middle of July.

WOOD (Gov. Wood)-One of the best cherries; very large; light yellow marbled with red; juicy, rich and delicious. Tree healthy and great bearer. Hangs well on the tree. Vigorous Last of June.

\section{DUKE AND MORELLO CHERRIES}

DYEHOUSE-A very early and sure bearer; ripens a week before Early Richmond. June.

EARIY RICHMOND-Medium size; dark red; melting, juicy, sprightly acid flavor. This is one of the most valuable and popular of the acid cherries, is unsurpassed for cooking purposes, and is exceedingly productive. Free. June.

LARGE MONTMORENCY-A large red, acid cherry, larger than Early Richmond and fully ten days later. Very profitable. Early Richmond hangs in clusters and is more liable to rot. Free. Last of June.

MORELIO (English Morello)-Medium to large; blackish red; rich, acid, juicy and good; very productive. Moderate. August.

PHILLIPPE (Louis Phillippe)-Very productive; fruit large, roundisk, regular, rich dark color, almost purplish black-red; flesh red, tender, sprightly; mild, acid; good to best. Free. Middle of July.

MAY DUKE-Large, dark red, juicy and rich; an old, excellent variety; productive. Free. Middle of June.

We do not hesitate to recommend our cherry trees to you, as we know that if given a trial they will more than measure up to expectation. Try them.

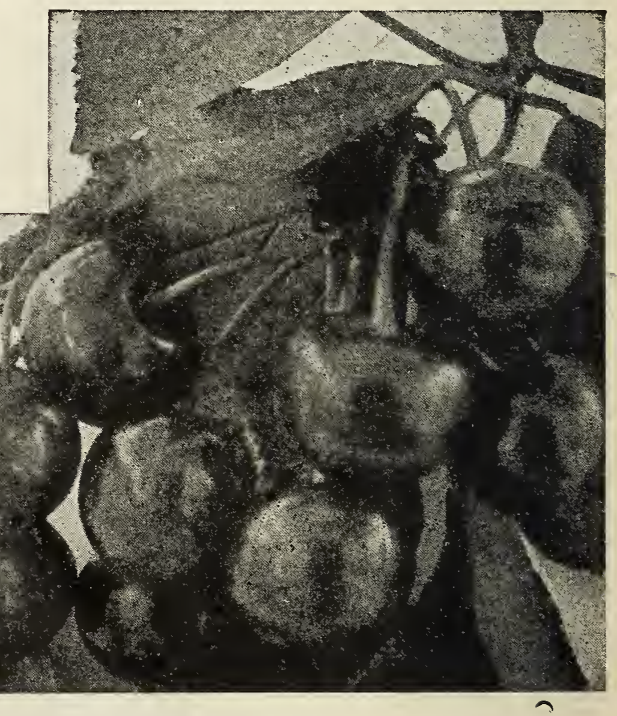




\section{DELICIOUS PEACHES}

The Peach requires a well drained moderately rich soil. Warm sandy loan is considered the most ideal, but hundreds of the best orchards in the Ohio peach belt are on heavy clay and others on heavy black loam. If you want the best all round Peaches, for home use or market, and varieties that will produce fruit and lots of it and trees that will stand the most severe winters, and bear when others fail. we have them in the following seven varieties of Special Mention.

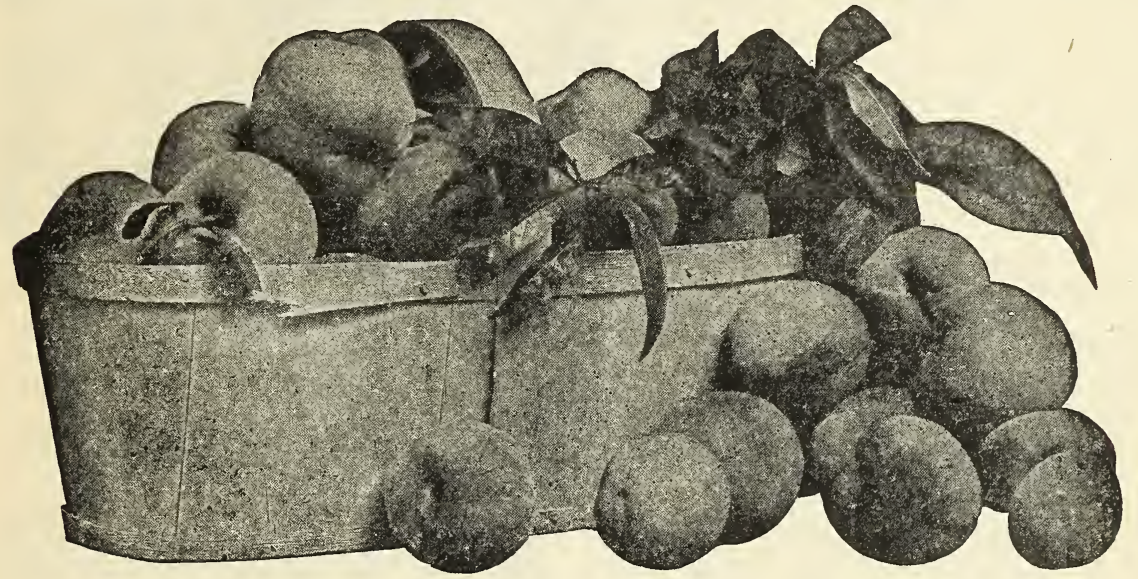

\section{VARIETIES OF SPECIAL MENTION}

These with the exception of the Hale and Wilma were introduced by us, some of thein over 20 years ago, and are varieties of local origin here in the peach belt of Northern Ohio. They have stood the test of time both in commercial orchares as well as in small home or chards, and have given the greatest of results whenever we have sold them. They have far surpassed our expectations and our claims for them.

We recommend the Briner, named from the man from whose orchard we first got buds, for large size, uniformity, freedom from disease, nature of foliage, and above all quality. As large as Elberta and 100 per cent better. As hardy as Elberta and all leading varieties.

We reconimend the other three for extreme hardiness both of tree and in bud. For fine quality and for being extra heavy and sure bearers. Fully as hardy, even if not more so, as Crosby or Golddrop, just as heavy bearers and as good flavor, and much larger.

In 1915 we saw several orchards of several hundred trees each in the Ohio peach belt, of Day's Nonpariel, loaded to the ground with highly colored fruit, and the size of the latter was a surprise, even to us. A large per cent would grade $\mathrm{AA}$, and the balance $\mathrm{A}$, and in one orchard of about 100 trees, which were heavily loaded last year, and as a consequence not quite as full this year, almost every peach would grade extra fancy, and was as large as any Elberta the grower had had. They were on good ground and well cared for. The grower had, however set two rows of them next to his Elberta orchard on the side toward a swamp for the reason that they would stand the lower and heavier soil better than Elberta or most anything else.

In another orchard of several thousand treese just at the close of the Elberta season, when someone wanted a real good peach to eat, the owner told him that he would go over to his Heidelburg orchard, where they had finished picking some ten days before and see if we could find a stray peach still left as he said whenever he wanted a good peach to eat for himself he always took a Heidelburg if he could get it, and that he considered it the best flavored peach that he had ever grown. And the richest, when canned.

We cannot recommend these varieties too high ly. If you want varieties that will bear when most others fail, trees that will stand the winters, trees that will do well on heavy soil, that will produce fruit, and lots of it, and of good size do not fail to plant them.

BRINER-Yellow free stone of finest quality large and is always evenly distributed over the tree so that there is very few small peaches mixed in. Tree of low branching habit, with the small, dark green type of foliage which is not subject to curl leaf. Equal to Elberta in size and superior in quality. Ripens a few days earlier than Elberta and stands shipping ordin. ary distances well.

DAY-Another heavy bearer of the very finest peaches, and a very hardy tree; yellow freestone and colors up well on the tree. Originated in our orchard. One large peach grower says: "I would rather lose any other variety in my orchard than the Day's Nompariel.' Good size, but should be thinned for market growing. Ripens between Late Crawford and Smock.

J. H. HALE-This is the new variety advertised so extensively and sold in immense numbers throughout the covntry in the last three years. Claimed to be a few days earlier than Elberta, larger, and better, and just as good a bearer as that variety. We offer fine trees at san ordiwary price.

HEIDELBURG-The reach par-excellence for home use; yellow freestone of good size; delicious flavor and small pit; hardy tree and heavy bearer. A splendid market variety and stands shipping well. Ripens just after Early Crawford, 
SATBERTA-Is a Salway-Elberta oross grown from an Elberta pit. A large yellow freestone of the fin. est quality ripening about three weeks after Elberta. In a letter received from the originator written October 4, 1916, Mr. Rofkar states that he was picking the Salberta then. The variety is also very hardy in bud. This variety gives us a continuation of the Elberta season, and ripens at the same time as Smock, and has proved to be a heavy and sure bearer. In our opinion it is destined to take the place entirely of the Smock as a commercial va. riety.

WILIMA-A late Elberta introduced by Mr. Rofkar of Catawba Island, $\mathrm{O}$, a few years ago and now bearing in that section in many orchards. It is a large yel. low freestone, highly colored, and more prolific than its parent Elberta, and about ten days later in ripening. It also starts growth a little earlier in the spring than other varieties.

WINSTONE-A seedling of Late Crawford which it resembles in every way, but tree is much hardier. During the severe winter of

1904 we had a tree of Winstone and one of Late Crawford standing side by side in a small test orchard. The latter tree was killed completely but the Winstone, a few feet away was uninjured and bore fruit the following season. This was also true of the Heidelburg and Day's Non. pariel while many of the old varieties such as Elberta, Crawford's Early and Late and others were entirely killed.

One customer writes us, after trying to get an orchard of Day and Winstone for several year's, but putting off ordering each time till the trees were sold out to send him all the trees of those varieties we had left (which was several hundred at that time) hecause he says that he wants trees that will produce peaches and is tired of planting the ordirary varieties which

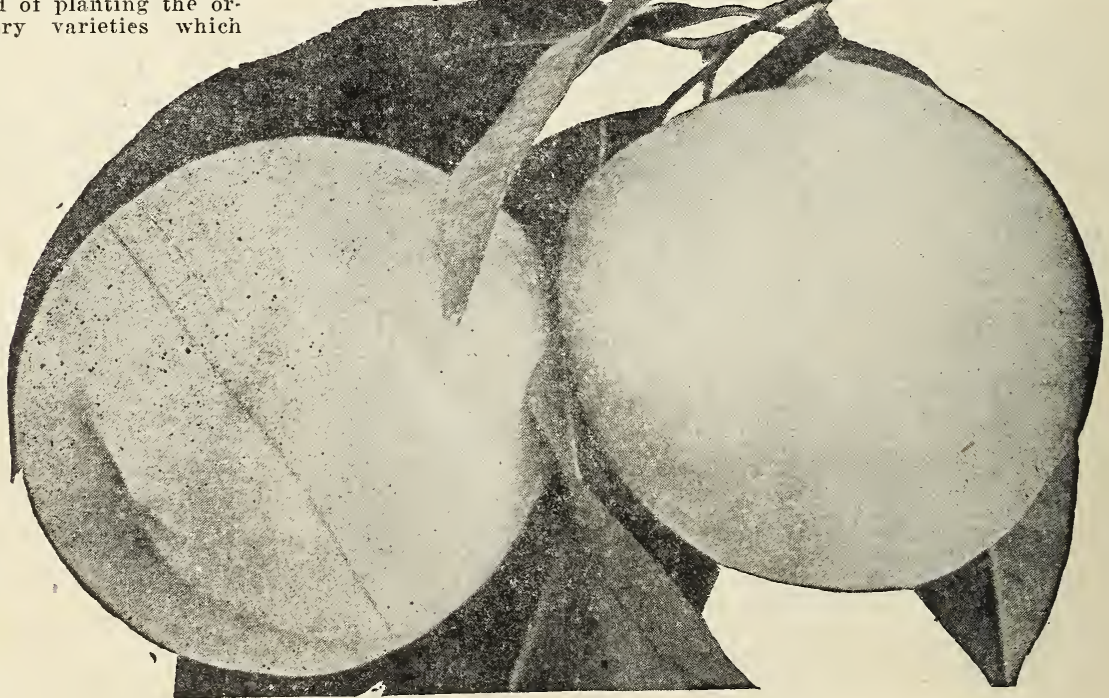




\section{LEADING PEACH VARIETIES}

ALEXANDER-Medium, greenish white, nearly covered witl rich red; melting, juicy sort. July. BANNER - A Canadian origination; one of the most profitable varieties ever produced. Fruit large, round and very handsome. Tree hardy and an abundant bearer. Season October first. BARNARD-Medium to large; yellow, cheek purplish red; flesh yellow, red at the stone: juicy, sweet, rich. One of the best yellow flesh. ed peaches. Freestone. Said to be nearly the same as Yellow Honest John and Yellow Alberge. First to middle of September.

CARMAN-Large, resembles Elberta in shape; color creamy white or pale yellow with deep blush; skin very tough, flesh tender, fine flavor and quite juicy. Ripens with Early Rivers. Promises to stand at the head for a general long distance, profitable market variety, in quality ranking superior to anything ripening at same time. August.

CHAIR (Choice Gydes)-Similar to Chair's Choice but a better bearer and hardy tree. Deep yellow with red cheek; firm; a few days earlier than Smock. September.

CHAMPION-A large handsome early variety, creamy white with red cheek, sweet, rich and juicy. Hardy and productive. August.

CROSBY - It unquestionably is one of the hardiest peaches of good quality yet introduced. It has borne immense crops where all other kinds in the same orchard were killed. The fruit is full medium size, round, oblate. Color bright yellow, beautifully splashed and striped crimson. The flesh is light yellow and red at the stone; firm; moderately juicy, and of good quality. It ripens about with old Mixon Free. Freestone.

DEWEY-It is a perfect freestone; flesh yellow, of uniform color and texture to the pit. Hardy and productive. Tree is strong, symmetrical grower, and as near perfection as we can obtain in a single variety. Early August.

EARLY CRAWFORD-This very beautiful and best of yellow peaches is highly esteemed for market purposes. Fruit very large, oblong; skin yellow, with a fine red cheek; flesh yellow, juicy, sweet and excellent. Wonderfully productive and hardy. Freestone. Last of August.

ENGLE-Large, yellow; resembles Late Crawford, more productive and later. October.

ELBERTA-A seedling of Chinese Cling but entirely free. Large, yellow with red cheek, juicy and of high quality; flesh yellow and melting A very valuable sort. Ripens after Early Crawford. Freestone.

FITZGERALD-An improved Early Crawford.

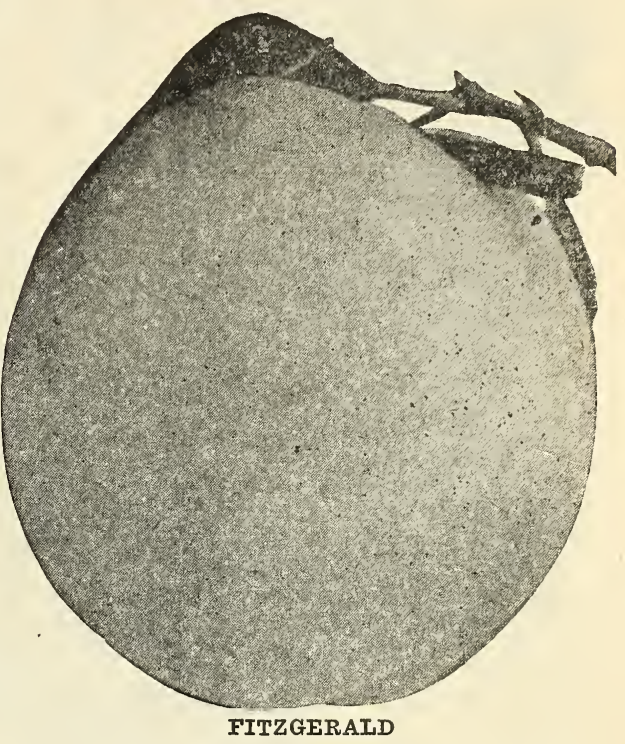

being fully equal to it in size, quality and color. Tree commences bearing young, is productive and one of the hardiest. Fruit large; brilliant color, bright yellow, suffused with red; flesh deep yellow, best quality. Early September.

HADDEN-A good early white freestone, similar to Mt. Rose but better; ripens a few days earlier in fore part of August.

GOLD DROP - A very early and prolific bearer; fruit of medium size, of rich golden yellow. Quality good. September.

KALAMAZOO-A leading Michigan market sort; large, yellow, fine quality. Extra productive and profitable. September.

LATE CRAWFORD-Fruit of the largest size; skin yellow or greenish yellow, with dull red cheek; flesh yellow, productive. One of the finest late sorts. Freestone. Last of September. LEMON CLING-Large, pale yellow, dark red cheek; hardy and productive. September.

LEMON FREE-Lemon color and shape; large and very large if thinned on the tree; immense.

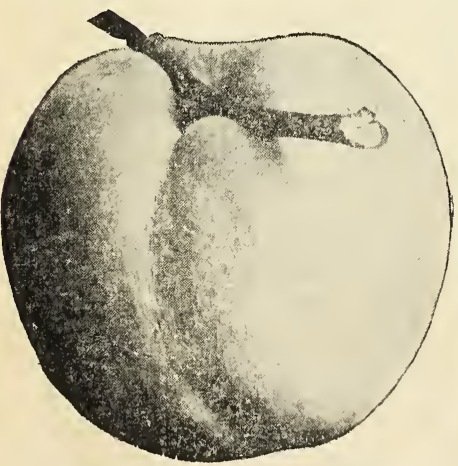

CARMAN, ONE OF THE BEST VARIETIES

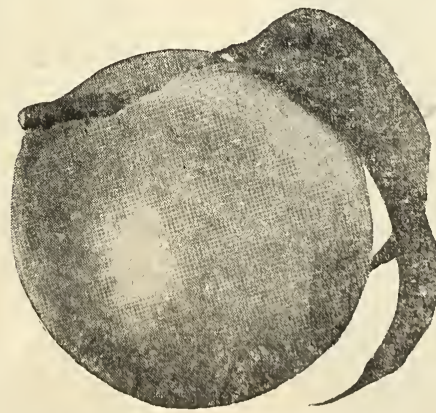

EARLY CRAWFORD, BEST OF YELLOW PEACHES ly productive and a very hardy tree. Especially esteemed and sought for by canning factories as it holds together well when camned. Last of September.

NEW P R O I I F I C Large, attractive, firm; flesh yellow, fine flavor; hardy and productive. September.

NIAGARA-Large, yellow, resembling Early Crawford but larger and a better bearer; a few days later. A new va. ricty in great demand by fruit growers in west. ern New York where it originated.

REYNOLDS (Melocotoon or Reynold's No. 1)- 


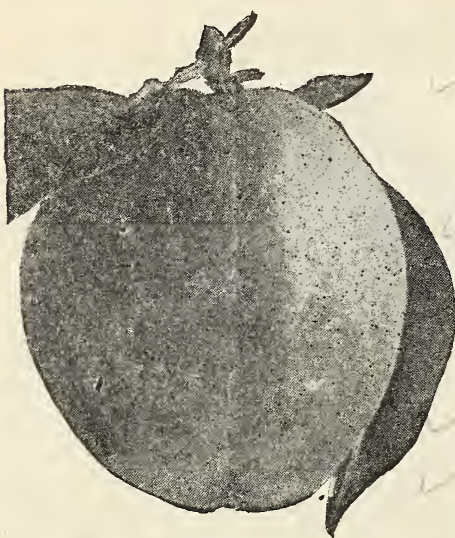

THE SALWAY PEACH
Of local origin but one of the best; yellow red cheek; good size and large if fruit is thinned; heavy bearer and hardy tree. Ripens nearly with Elberta.

SALWAY-Fruit large, roundish; deep yellow, with a rich marbled brownish red check; flesh yellow, juicy, rich and sugary. A new English variety, a good keeper and promising highly as a late showy market sort. Freestone. First of October. Too late in the north except near large bodies of water.

SMOCK FREE-The old strain of Smock, not as large as the Beers Smock but a much heavier bearer. Last of September. SMOCK (Beers)-An improved strain of Smock, being larger than the preceding but not generally considered as heavy a bearer. We are growing several strains of this variety. One known as the Kilkens, another as Thompson, whioh are bearing heavily in some orchards. A leading market variety. Sept. STUMP-Very large, roundish; skin white, with a bright red cheek; flesh white, juicy and good. Freestone. Last of Sep. tember.

ST. JOHN-Nearly as large as Crawford, fully equal in color. Fruit round, brilliant, showy; one of the earliest yellow peaches. August

Also Foster, Mayflower, Globe, Marshall, Mt. Rose, Old Mix on Free, Slappey, Sneed, Triumph and others.

\section{MULBERRIES}

The mulberry is valuable as an ornamental shade tree and the fruit is quite popular in some sections. It is especially valuable in poultry parks.

DOWNING AND NEW AMERICAN-Are by long odds the twe best varieties of Mulberries to plant for fruiting purposes. Both are very large, fine berries, black when fully ripe and continue to mature fruit for six to eight weeks in midsummer. The Downing is too tender a tree for our northern winters and we therefore recommend the New American which is much more hardy, and just as good in every way.

RUSSIAN-A valuable tree to plant for posts or timber, but fruit is usually too small to make it a desirable fruiting variety. Being a seedling, however, one is apt to find a great variation in different trees and sometimes a tree is found which produces fine fruit. It is always a valuable tree to plant near berry plan. tations to attract the birds from the more val uablo crops of raspberrios, blackberries, cur. rants, etc.

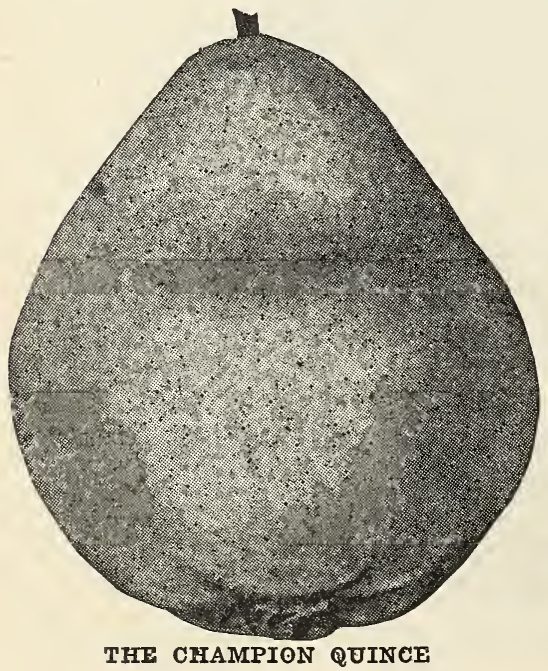

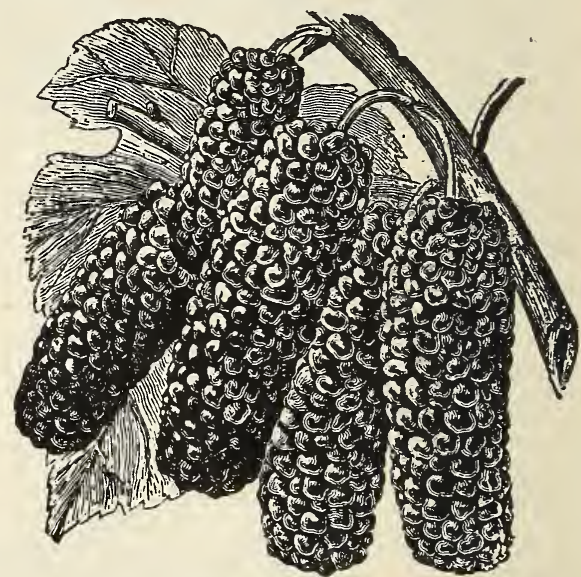

NEW AMERICAN MULBERRY

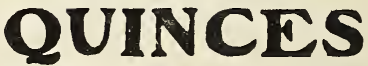

In quinces we have a very desirable fruit. It is used a great deal for preserres and can. ning especially with other fruits. A small part of quince will impart the quince flavor to three or four times as many apples. Quince syrup is very delicious, even excolling the finest maple syrup.

BOURGEAT-Tree a remarkably strong grower, surpassing all others, yielding immense crops. Fruit of large size, round; rich golden color; smooth; very tender when cooked; has been kept till February in good condition.

CHAMPION-A prolific and constant bearer, fruit averaging larger than the Orange, quality equally fine, and a long keeper; bears extremely young. Ripens late.

MEECH-A vigorous grower and immensely productive. The fruit is large, lively orange yellow, of great beauty and delightful fragrance; its cooking qualities are unsurpassed.

ORANGE (Apple)-Fruit large, round, with a short neck: color bright yellow; flesh firm and tough until cooked, when it becomes tender, juiey and of excellent flavor. We recommend the Orange as the best all around variety to plant. 


\section{ALWAYS ROOM FOR GRAPES}

The vines come quickly into bearing, yielding fruit usually the second year after planting, requires but little space, and when properly trained, is an ornament to the yard, garden or vineyard.

As a commercial crop there is nothing more satisfactory. They are as reliable as a corn crop, and as staple on the market as wheat. When a vineyard is once established it will be productive for a life time with ordinary care, and the income from it can be counted on almost as certainly as the changing of the season. Grapes do well on either gravelly, sandy soil, or a combination of these. If planted on clay soil, it must be thoroughly underdrained to secure good results.

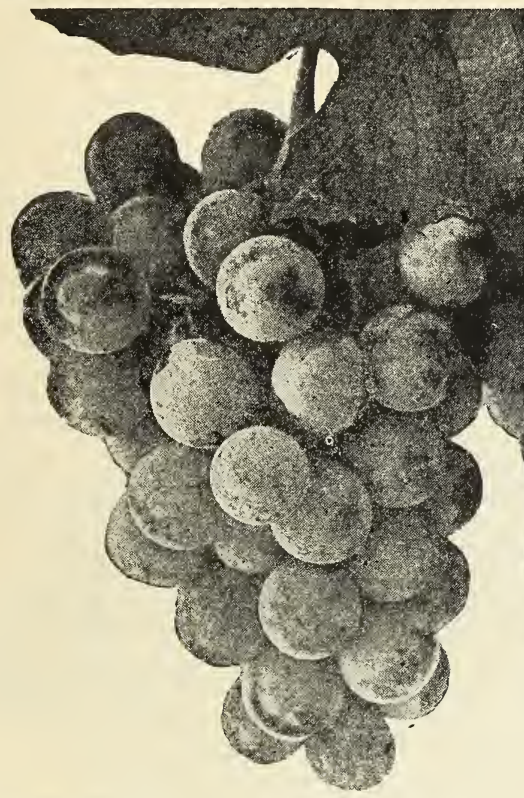

BRIGHTON-A cross between the Concord and Diana Hamburg. It gives the best satisfaction. Bunches large, berries of medium size, dark red; flesh sweet, tender and of the highest quality. Ripens one week earlier than Dela. ware. First of September.

CAMPBELL'S EARLY-Clusters large and handsome; berries large, nearly round, black, with light purple bloom; flesh rather firm, but tender; seeds few and easily separated from pulp; quality rich, sweet, slightly vinous; strong vigorous grower, with healthy foliage; ripens very early; berries do not drop easily from clus. ters, and the fruit keeps a long time in perfection; promises to be of great value.

CATAWBA-Bunches large and loose; berries large, of coppery red color, becoming purplish when well ripened; later than Isabella; requires the most favorable soils and situations, good culture and warm seasons, to mature perfectly in Western New York. Last of September.

CONCORD-A popular variety where the choice kinds fail to ripen; universally healthy, vigorous and productive; flesh somewhat buttery, moderately juicy and sweet. Bunch large, nearly black with bloom; early. September.

DELAWARE-Still holds its own as one of the finest grapes. Bunches small, compact, shouldered; berries rather small, round; skin thin, light red; flesh very juicy, without any hard pulp, with an exceedingly sweet, spicy and delicious flavor. Vines moderately vigorous, very hardy and productive. September.

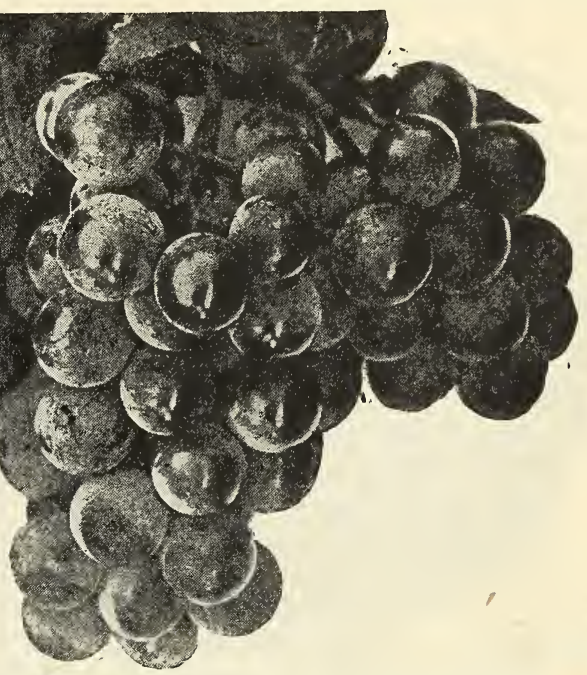

DIAMOND-White; bunch large, compact, shouldered; berries large, round; skin thick; firm; flesh tender, juicy, with but little pulp. Vine a good grower with thick, healthy foliage; said to be hardy and productive. September.

MOORE-A seedling of Concord, combining the vigor, health and productiveness of Concord, and ten days earlier than Hartford. In quality hardly to be distinguished from Concord. Bunch large, berries very large, black. August.

NIAGARA-Bunch medium to large, compact, occasionally shouldered; berry large, roundish, uniform, of pale greenish color; flesh slightly pulpy, tender, sweet. Vine remarkably vigor. ous, healthy and productive. September.

POCKLINGTON-It is a seedling from Concord; fruit a light golden yellow, clear, juicy and sweet to the center, with little or no pulp; bunches very large, sometimes shouldered; berries round, very large and thickly set. First of September.

WORDEN-Bunches large, handsome, double shouldered; berries large, sweet. Being ten days earlier than Concord, it ripens well in cold localities; vine very thrifty and vigorous, perfectly hardy and a good bearer. It is coning rapidly into repute as one of the leading sorts for general cultivation, ranking in this respect with Concord, to which it is decidedly superior in quality; black. Middle of September.

WYOMING-An early, light red grape with iron clad vine and foliage; always yielding enormous crops. It ripens with Delaware, which it resembles in appearance, although larger in bunch and berry. A valuable grape for market growing. 


\section{STRAWBERRIES}

To insure best results Strawberries should be freshly dug, packed by themselves and shipped by express. We never dig them till we are ready to ship and consequently have usually had good success even when we sent them by freight along with other stock. They should always be attended to and planted at once on receipt of goods. We grow eighteen or twenty of the best varieties and our list is changing most every year. Varieties with imperfect or pistillate flowers are marked "'P," those with perfect or staminate flowers are marked "S.", Where pistillate varieties are planted, every third or fourth row should be some staminate variety that blossoms at the same time, in order to produce plenty of pollen to fertilize the imperfect flowers of the pistillate sorts.

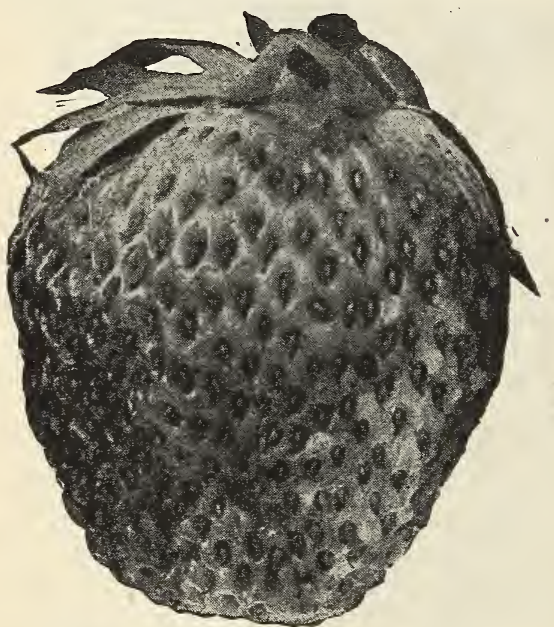

GLEN MARY, LARGE TO VERY LARGE

BRANDYWINE (S)-Large, mid-season to late, of excellent quality, dark glossy red; healthy, vigorous and productive. One of the best for all purposes.

CRESCENT (P)-Early, of medium size, bright scarlet. An old, well-known variety. Very productive.

GANDY (S)-Large, late, firm, bright crimson; uniform in size and shape. Vigorous and productive; one of the best late varieties.

GLEN MARY-Berries large to very large, often flattened, bright deep red on surface, light red to center, sweet, rich, good flavor. Season medium to late. One of the most productive and holds its size to end of season. Plant very vigorous. One of the best for home use and near by market.

HAVERLAND (P) - Medium to large, long conical, of fair quality; rather soft, but a popular market berry.

JESSIE (S)-Large, bright red; very popular where it succeeds. An excellent fertilizer for Bubach and other blooming kinds. Very fine quality.

NICK OHMER (S)-Very large, dark red, uniformly roundish conical, of excellent quality, very healthy, vigorous and productive. One of the very best extra large varieties.
DUNLAP (S) -A well-tested, wonderfully productive variety, one of the safe sorts to plant everywhere and sure to take a high place among the prominent standard sorts. Plant resembles Warfield, rampant runner, should be restricted in its production of plants, fully equal to Cres. cent and Warfield in its ability to succeed under all circumstances. Fruit good size, regular form, beautiful bright red, glossy, firm, splendid keeper and shipper, excellent quality; one of the best for canning; ripens early and continues a long time. It promises to stand at the head in its wonderful ability to ripen a good crop under almost any condition of drought or neglect.

WARFIELD (P)-The great market berry of the central and northern part of the country. Famous for its llaming color. great firmuess and unsurpassed flavor. Many hotels and restaurants in the great cities advertise Warfields strongly as one of the season's attractions, so much is for its fame for flavor and lusciousness. As a canning berry it has no superior and is a valuable shipper, comes in early and is enormously productive.

WILLIAM BELT (S)-Large, conical, bright scarlet, firm, of good quality; vigorous, healthy and productive.

WILSON (S)-The old standard, rich, dark red, very firm and good quality. Extensively planted for shipments to distant markets.

Strawberries are one of the most common and extensively used varieties of our small fruits and as a commercial proposition are grown in large quantities at very satisfactory profit. 


\section{Fall or Everbearing Strawberries}

The Everbearing Strawberry is now past the ex-quarts of fine berries to a picking, three times a perimental stage. We were skeptical ourselves at first and before offering them to our trade we tested them several years. Out of a number of varieties tested we found only two or three that succeeded. Two of these sorts were so far ahead of any others that we tested that we have dropped all others and will offer these two only. They are the Superb and the Progressive and the former was more satisfactory than the latter. We picked from a small bed of between 200 and 300 plants, all planted in the spring of the same season, from four to five week beginning fore part of Angust and con tinuing till freezing weather. The vines were covered with blossoms and green and ripe ber. ries at all times. We believe that every one should have some of these for a novelty, but we do not believe that they will be a paying pro. position commercially.

We offer plants of Superb and Progressive. Superb has averaged larger and has produced more quarts with us, while Progressive has produced more berries, but smaller and on longer, more upright stems.

\section{RASPBERRIES}

Raspberries are one of the most delicious and popular fruits grown, are easily cultivated and require little care. Cut out old and weak roots each year. Plant in good soil in hills about four feet apart. With a little care and attention they will produce large crops of berries. In large plantings it is advisable to plant them thickly the same as hedge row.

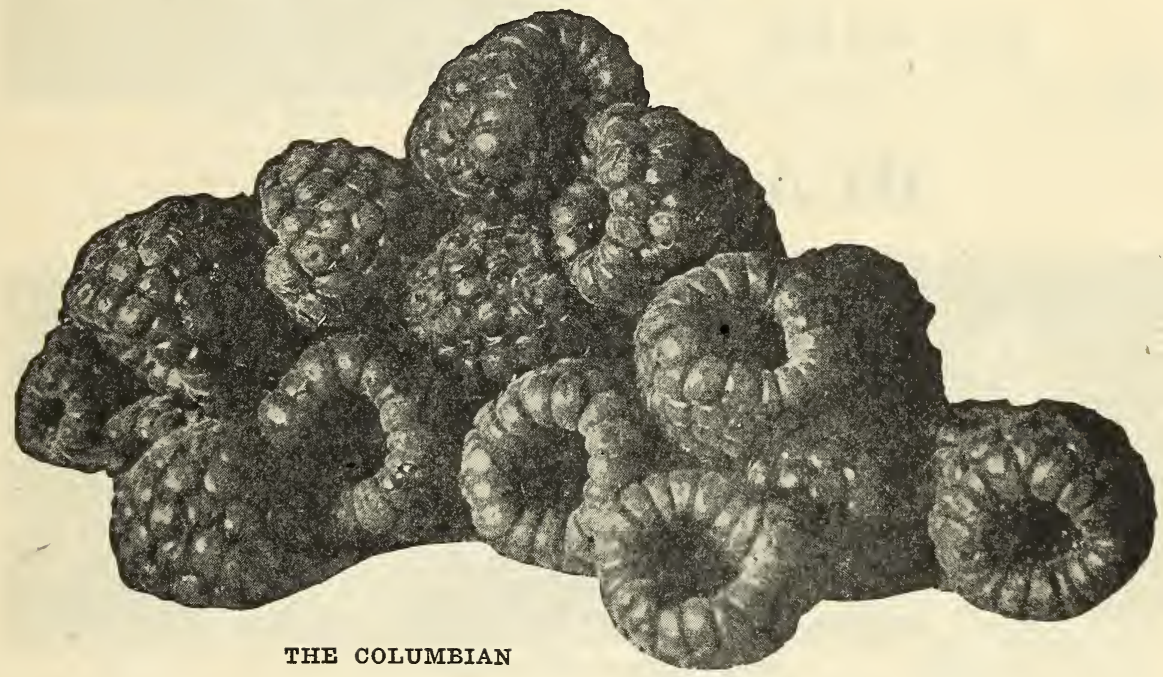

\section{RED AND PURPLE VARIETIES}

COLUMBIAN (Purple Cap)-The Columbian is a variety of the Shaffer type; of remarkable vigor and productiveness. It is very hardy and a rank, thrifty grower; propagates from the tips, same as black caps. Fruit very large and grows abundantly; very rich flavor, tarty, a splendid berry for jelly, pies and for canning.

CUTHBERT-Leading late variety, all over the country. A very rank grower. Very produc. tive. Fruit large and of good quality. If you want a good all round late red raspberry, plant the Cuthbert.

HAYMAKER A purple cap, not so dark as Columbian or Shaffer, and larger and firmer than either of those varieties; never crumbles, and stands up well in shipping. Sample crates have been shipped to distant points with entire satisfaction. It is a berry to grow for either home use or market.

ST. REGIS-The so-called everbearing variety. This has borne some berries in the Fall but has not proved much of a success with us.

\section{YELLOW VARIETIES}

GOLDEN QUEEN-A seedling of Cuthbert equaling that variety in vigor of bush and pro. ductiveness. Fruit large; color a pure yellow; quality best. Ripens with Cuthbert.

\section{BLACK CAPS}

CUMBERLAND-The largest of all the black caps; coal black berries; very firm and quality of the very best; excellent shipper. Bush \& strong grower, stocky canes and unusually prolific. Mid-season.

GREGG-One of the most valuable varieties of the black cap family; fruit larger than Mam. moth Cluster, but not quite so good in quality; ripens some days later; hardy, a vigorous grower and great yielder.

KANSAS-A seedling originated at Lawrence, Kansas; ripens soon after the Palmer. Berries as large or larger than Gregg; jet black, and of the very best quality. It has been thoroughly tried out at the Experimental Station, and is favorably recommended. It stands the trying 
climate of Kansas, where nearly all other varieties fail. It has become a standard variety over a large part of the country.

NEW LOGAN-Here is the berry we have been seeking for years. As large as Gregg, earlier than Cumberland, and more productive than either. Resists drought perfectly and holds up well during the entire season, being far su. perior to Cumberland in that respect. More hardy in winter and less susceptible to disease than Cumberland. We are replacing our plantation of Cumberland with the New Logan and the King of Cliffs. These two varieties have been thoroughly tested in this vicinity for a number of years and have held up to expectations in every case.

KING OF CLIFFS-Imported from Illinois to this vicinity, but we can see no difference in this from the New Logan. Our supply of plants of these two varieties will be limited.

\section{ASPARAGUS}

CONOVER-Very large size and of excellent quality; has superceded the old varieties.

Also Columbian Mammoth White, Palmetto, etc.

\section{RHUBARB}

MYATT-Early, very large, tender and delicately flavored; requires less sugar than other sorts.

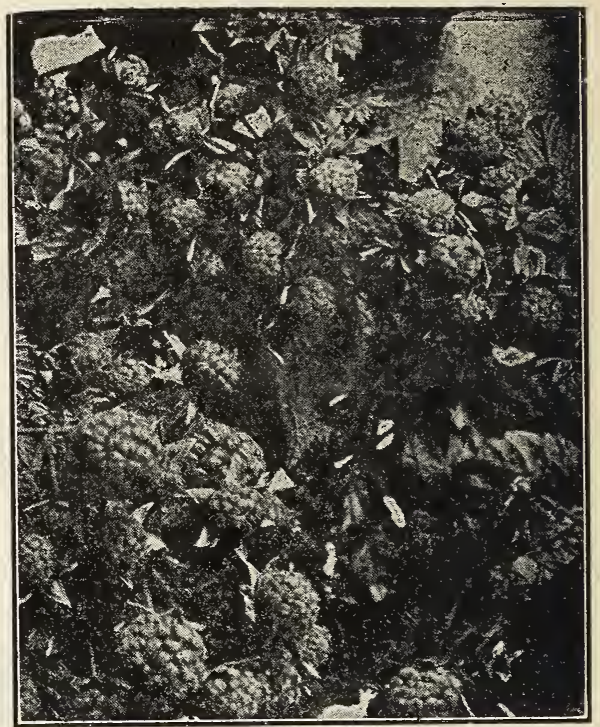

NEW LOGAN

\section{BLACKBERRIES}

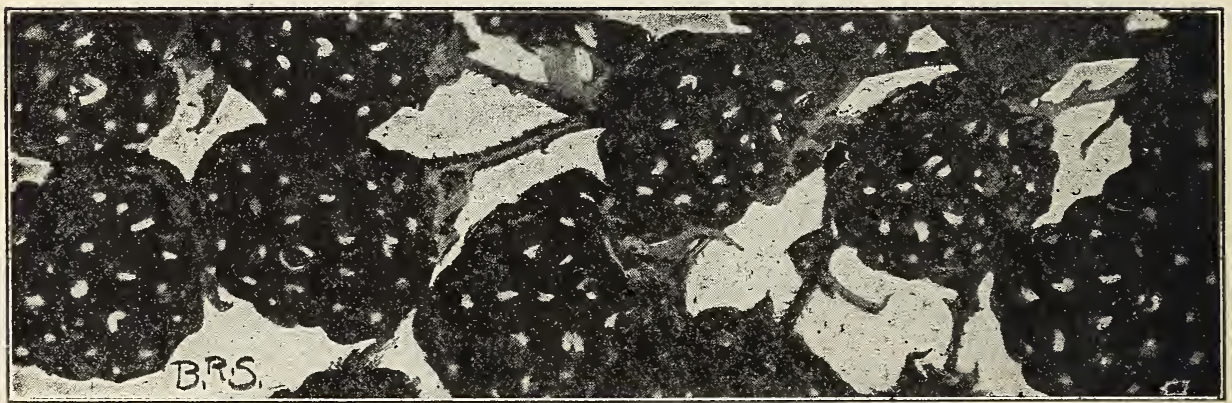

THE TAYLOR BLACKBERRY

We grow our blackberry plant from root-cuttings, and in this way get plants with plenty of fibrous roots, which make sure the growing of the plant. In fruiting patches of blackberries there will spring up many plants from the root, and these are the plants that are usually dug up and sent out to the trade. They have but few, if any, fibrous roots, and are much more apt to die when planted, and will not make the growth after planting that the plants will when grown from root-cuttings.

BLOWER-Originated in the celebrated small fruit belt of Chautauqua County, N. Y., where it has been thoroughly tested for several sea. sons. Claimed to be the hardiest, most productive, the finest quality and to bring on the market the highest price of all blackberries. Has produced 2694 berries on one bush, 2720 quarts on one-third acre. Large size, jet black, good shipper, best quality, unexcelled productiveness are the main characteristics of this splendid new sort.

ELDORADO-A valuable new variety; fruit medium size, jet black, melting, sweet and rich, plant hardy and very productive.

ERIE-This is a hardy blackberry that origin. ated near Lake Erie. The bush is healthy and very productive, as well as hardy; fruit large, round, jet black and good quality. Ripens very early and is a decided acquisition.

SNYDER-Extremely hardy, enormously prodnc. tive, medium size, no hard, sour core, half as many thorns as Lawton or Kittatinny, and they are nearly straight and short; exceedingly pro. ductive.

TAYLOR-One of largest blackberries grown. Very productive, and as hardy as the Snyder.

IUCRETIA DEWBERRY-The best of the blackberry family. Berries are far larger and better than any blackberry; of unequalled excellence; sweet and luscious throughout, of brightest glossy black color. Its trailing habit renders it less liable to winter kill. Propagates from the tips. Plant in rows six feet apart and plants three feet apart in the row. 


\section{GOOSEBERRIES}

Gooseberries should be planted in good, rich soil and well manured once a year. Pick regularly, thoroughly cutting out all dead-wood and surplus branches. Plant in rows 4 feet to 6 foet apart in row. It is well to mulch heavily in the fall. Plants are hardy, rugged and easily grown.

COLUMBUS-This is one of the most valuable introductions of recent years in small fruits, and

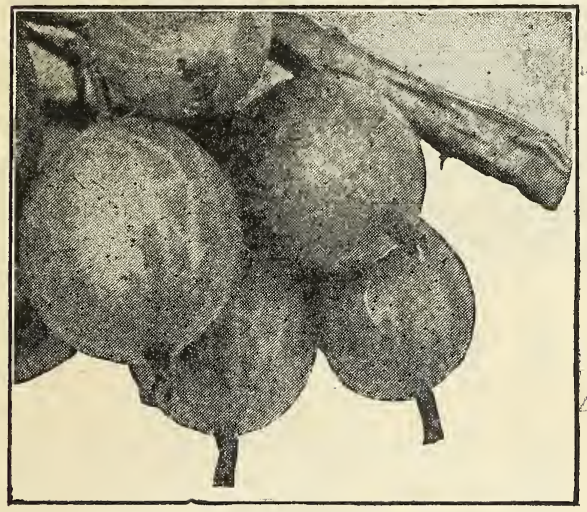

THE DOWNING GOOSEBERRY it fully sustains the high opinion first formed of it. The fruit is of largest size, handsome, of a greenish yellow color, and the quality is excellent. The plant is vigorous and productive and does not mildew. It merits a place in every garden.

INDUSTRY-An English variety; quite as free from mildew as our American sorts; very fine in quality; large size. Handsome, showy, red fruit; wonderfully productive.

DOWNING-Fruit larger than Houghton, round ish; light green, with distinct veins; skin smooth; flesh rather soft; juicy and very good. Vigorous and productive. The most popular variety for market growing.

HOUGHTON-A medium sized American varie ty, which bears abundant and regular crops and never mildews; fruit smogth; red, tender and very good; valuable.

JOSSLYN (Red Jacket)-An American seed ling of large size; smooth, prolific and hardy, of best quality. Has been well tested over a wide extent of territory by the side of all the leading varieties, and so far the freest from mildew, both in leaf and fruit of them all. A wonderful cropper, with bright, clean, healthy foliage.

\section{CURRANTS ARE HEALTHY}

The currant is one of the most reliable of small fruits. They mature just before raspberries and can be used either raw or cooked. Being hardy, they do not winter kill, are easy of cultivation and require little care. They can be grown in any good garden soil. The market is never oversupplied. Prune out dead wood, and mulch heavily. If currant worms appear dust with hellebore.

BLACK NAPLES-Very large, black; rich, ten. der and excellent for jellies and wine; very productive.

CHERRY-Very large deep red; rather acid; bunches short, plants erect, stout, vigorous and very productive.

FAY-Color deep red; great bearer; stems long. er than Cherry, and berries hold their size to end of stem better. Quality first class; not quite so acid as Cherry; the best of all the red currants.

LONDON MARKET-For many years this va. riety has been fruiting in Michigan where it is now planted extensively and regarded as the best market variety of that great fruit state.

PERFECTION (Red)-This truly wonderful new currant has both large size and extra good quality. Perfectly healthy, a vigorous grower, and in fact an extra fine red currant in every way. Widely advertised all over the country.

VERSAILLES-Large, red; bunch long, of great beauty and excellent quality; one of the finest and best, and should be in every collection. Very productive and valuable for the table.

WHITE GRAPE-Very large, yellowish white. The finest of the white sorts. Very distinct from White Dutch, having a low spreading habit and dark green foliage. Very productive.

WILDER-Very large; bright red and attractive; a splendid market sort; not so acid as most. Bush very productive; large bunohes: ripens rather early; fruit keeps well.

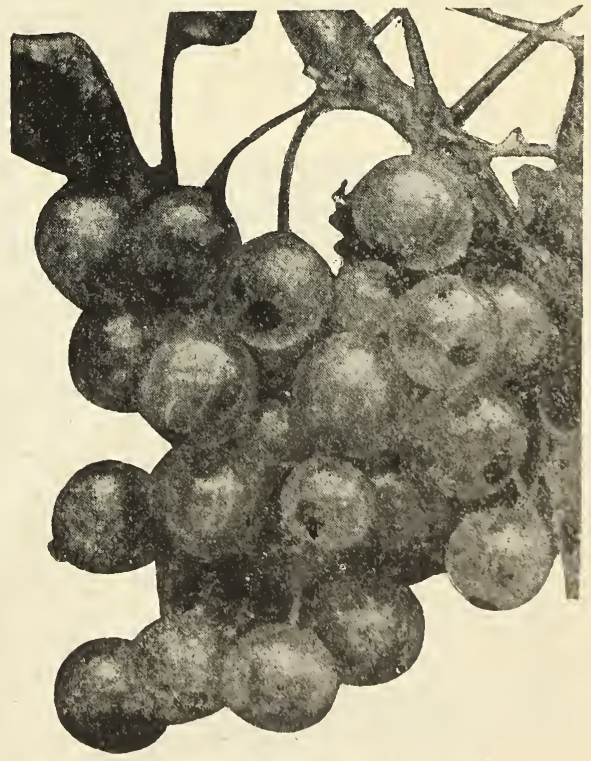

WILDER CURRANT 


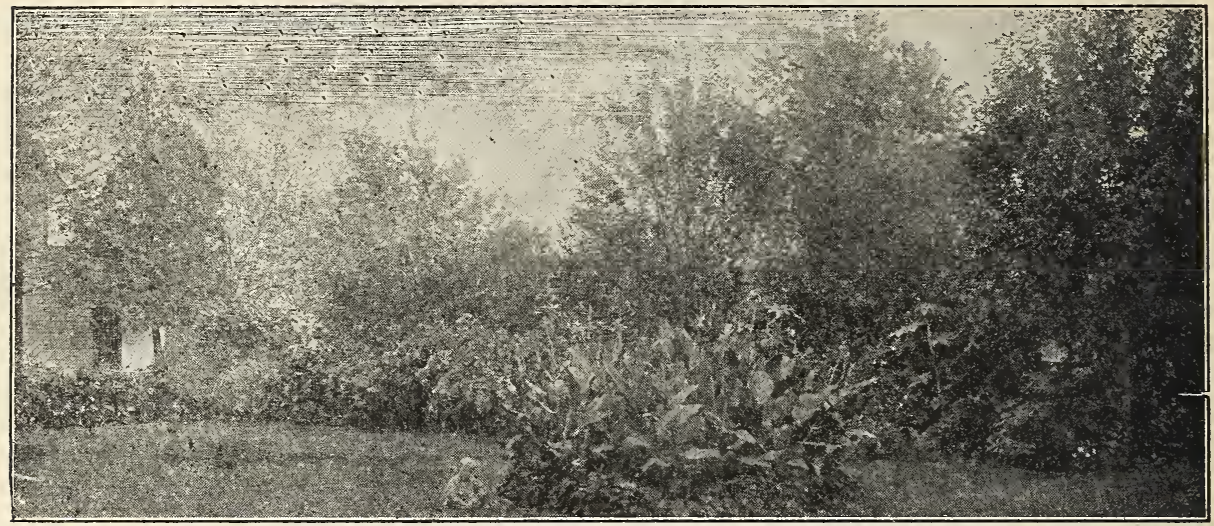

\section{DECIDUOUS TREES}

\section{NUT TREES}

CHESTNUT (American Sweet)-A valuable native tree, useful and ornamental; timber is very durable, and possesses a fine grain for oil finish. Nuts sweet, or delicate flavor, and are a valuable article of commerce.

CHESTNUT (Spanish)-A handsome round headed tree, producing abundantly very large nuts that find a ready market at good prices. Twenty-five dollars have been realized at one fruiting from the nuts of a single tree. Not as sweet as the American and tree not as hardy. WALNUT (Japan Sieboldi)-Perfectly hardy here, rapid grower, handsome form, immense leaves; bears young and abundantly; one of the finest ornamental trees. Nuts produced in clusters; resembles Butternut in shape and qual. ity; smaller with smooth and thinner shell. It is worthy of extensive planting.

Also Black Walnut, English Walnut, Pecan, etc.

ing appearance. Early in the season the foliage is deep purple, later changes to erimson, and again, in the fall, to a dull purplish green. Forty to fifty feet when fully grown.

\section{BIRCH}

EUROPEAN WHITE (Alba)-Silvery bark and slender branches. Fifteen to thirty feet high when fully grown.

\section{CATALPA}

The Catalpas flower in July when few varieties are in bloom, and are therefore desirable. The blossoms are large and quite fragrant. Large, heart shaped, yellowish green leaves. Very effective, tropical looking lawn trees.

BUNGEII (Chinese Catalpa)-A species from China of dwarf habit, growing only from three to five feet high. Foliage large and glossy; a shy bloomer. Top grafted on tall stems it makes an effective umbrella-shaped tree.

\section{ELM}

AMERICAN-A very large, rapid growing native IMPERIAI CUT LEAF-Of stately, graceful AMERICA cut foliage. Vigorous

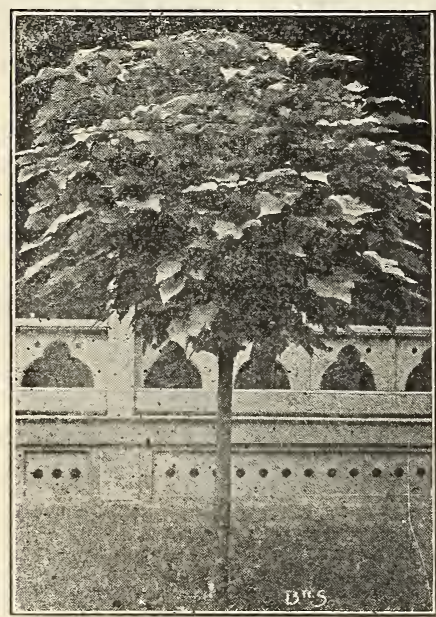

CATALPA BUNGEII and very hardy. At. tains a height of about 20 feet.

\section{AMERICAN CRAB} BECTHEL'S DOUBLE FLOWERED - One of the most beautiful of the many fine varieties of flowering crabs. Tree of medium size, covered in early spring with large, beautiful, double fragrant flowers of a delicate pink color. From a distance the flowers have the appearance of small roses. A great acquisition, and certain to become very popular as soon as it is known. Blooms when quite young.

\section{BEECH}

PURPLE I EA V E D (Purpurea) -A most ele. gant lawn tree, of strik.

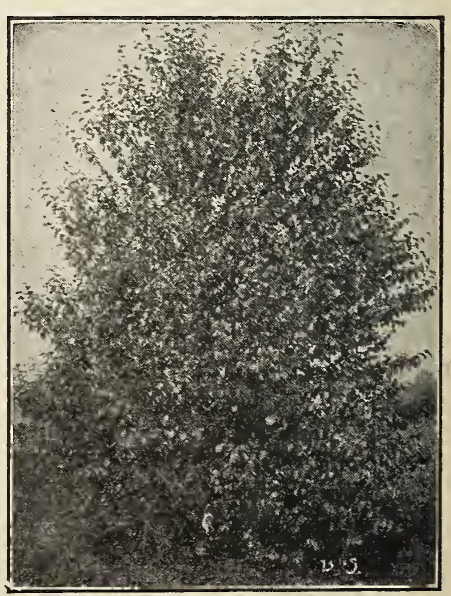

THE BEECH 
tree with broad, spreading and drooping head Very valuable for shade or timber. Hardy and succeeds well on most any soil, even adapted to low, wet black soils.

\section{HORSF CHESTNUT}

WHITE FLOWERING-Decidedly the finest variety of this family. Makes a beautiful tree of regular outline. Exceedingly hardy and free from all diseases. Covered in May with magnificent white flowers tinged with red. Forty to fifty feet when fully grown.

\section{MAGNOLIA}

By many considered the finest and most beautiful small tree to be had. Owing to difficulty in transplanting, unless taken up with the earth on the roots, we handle only the imported Holland plants, which are always taken up in that way. These are perfectly hardy here, and it is very seldom that one fails to grow. They are fine specimen plants about four feet tall, and well set with buds which bloom the first season. SOULANGEANA-Shrubby and branching while young, but becoming a fair sized tree. Flowers white and purple, cup shaped and three to five inches in diameter. Flowers large, glossy and massive. We recommend this as the best.

SOULANGEANA NIGRA-Immense blackish flowers blooming later than the preceding, and tree a little more dwarf growing.

\section{MAPLE (Japanese)}

DARK PURPLE LEAVED-Forms a bushy shrub; foliage dark purple and deeply cut; very ornamental. The hardiest and altogether the best of the Japan Maples One of the choicest small trees or shrubs in the catalogue.

BLOOD LEAVED-Of dwarf habit and rounded form; foliage five-lobed and serrated; reddish crimson in June and remaining reddish most all season; one of the very best.

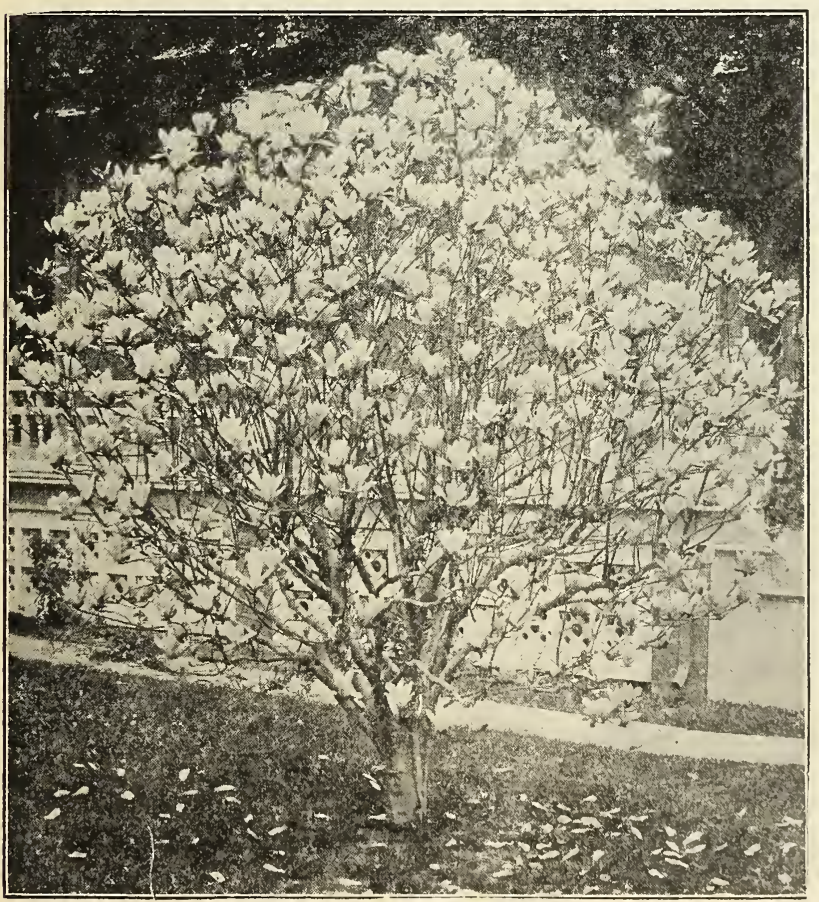

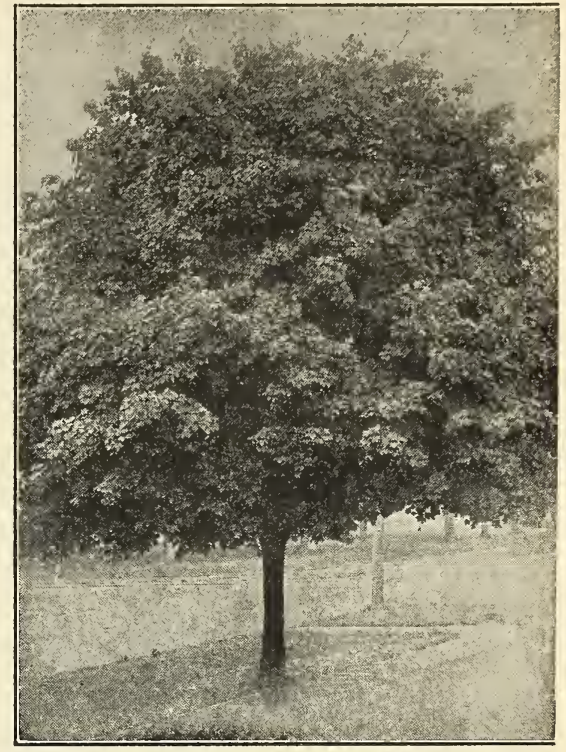

SCHWEDLER'S MAPLE

\section{MAPLE}

The vigorous growth, fine form, hardiness, freedom from disease, and adaptability to all soils, renders the maple one of the best of trees for the purpose of shade. It has few equals for the street or park.

ASH IEAVED-A hardy native sort. Ash-like foliage, spreading head. Rapid growth. Hardy.

SUGAR OR ROCK-The well known native variety. Valu. able for the street or park. Fifty to sixty feet when fully grown.

NORWAY (Platanoides) Large, compact habit, and broad, deep, green, shining foliage. A stout, vigorous grower. One of the best for the street or park. Forty to fifty feet when grown.

SCHWEDLERI - A beautiful variety of Purple Leaf Norway with long shoots and leaves of bright purple and crimson color, which change to purplish green on the older leaves.

SILVER LEAVED OR WHTTE -Foliage bright green above and silvery underneath. An exceedingly rapid grower, and makes a large tree.

WIER'S CUT LEAVED Grows rapidly, and the shoots are so slender and drooping that it has a decidedly graceful appearance. The leaves are deeply and delicately cut. A large tree if undisturbed, but will stand severe pruning, and so may be easily adapted to small places. 


\section{MOUNTAIN ASH}

EUROPEAN-A more desirable variety than the American, being of finer growth and form. It blossoms during the early spring, after which the bright scarlet berries are formed in clus. ters. Twenty to thirty-five feet when fully grown.

\section{POPLARS}

Poplars are desirable where rapid growing varieties are wanted, and they are also very distinct and striking.

CAROIINA-Of compact habit. A very rapid grower. A desirable tree for the seashore and for our large cities, where escaping gas kills most shade trees. Fifty to sixty feet.

IOMBARDY-From Italy. Remarkable for its erect, rapid growth, and tall, spiry form. Of great value for planting with other trees to break the average height and form. Fifty to seventy-five feet.

NORWAY-Similar to Carolina but even a faster grower than that sort Leaves deeper green.

\section{SYCAMORE}

As an ornamental tree for large grounds, or as a shade tree for street planting, this has no superior. It is a rapid grower, attains a large size, and presents a striking combination of majesty and gracefulness. The foliage is heavy and not subject to ravages of insects.

\section{TULIP TREE}

A very large native tree. Pyramidal habit, with broad, fiddle-shaped leaves. 'Tulip-like flowers. Also Dogwood, Flowering thorn, Ash, Flowering Peach (red and white), Flowering Cherry, Oaks, Salisburia, Willows, European Linden or Bass wood, etc.

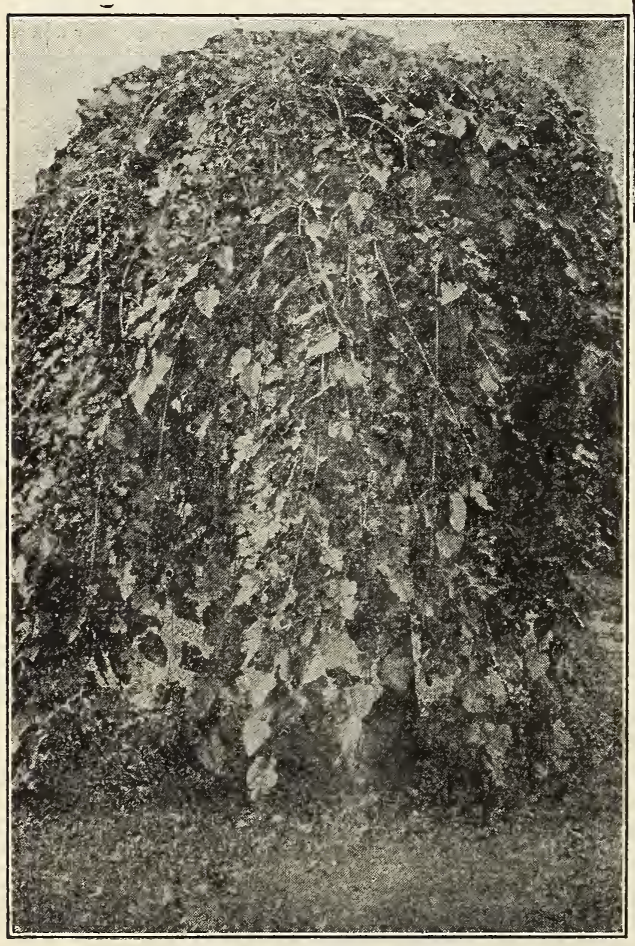

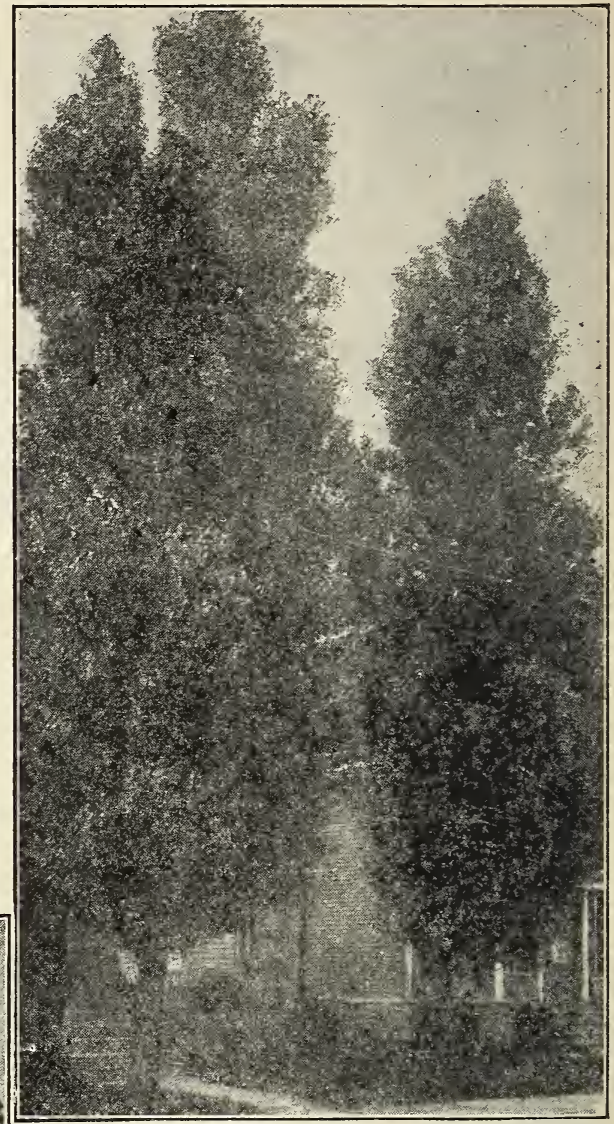

THE LOMBARD POPIARS

\section{Weeping Deciduous Trees BIRCH}

CUT-LEAVED WEEPING (Pendula laciniata) This tree is indeed a picture of delicacy and grace. It presents a combination of attractive characteristics of which no other variety can boast. Mr. Scott in his "Suburban and Home Grounds," says of it: "No engraving can do it justice; like the palm tree of the tropics, it must be seen in motion, swaying in the lightest breeze, its leaves trembling in the heated air, its white bark glistening through the bright foliage and sparkling in the sun, to enable us to form a true impression of its character." Makes a large tree. Of but little beauty when delivered from the nursery, but it develops into a thing of beauty.

\section{MULBERRY}

TEA'S WEEPING-Perfectly hardy, forming a natural umbrella-shaped top or head; foliage handsome; a fine ornamental for the lawn.

Also Weeping Willows, Japanese Weeping Cherries, etc. 


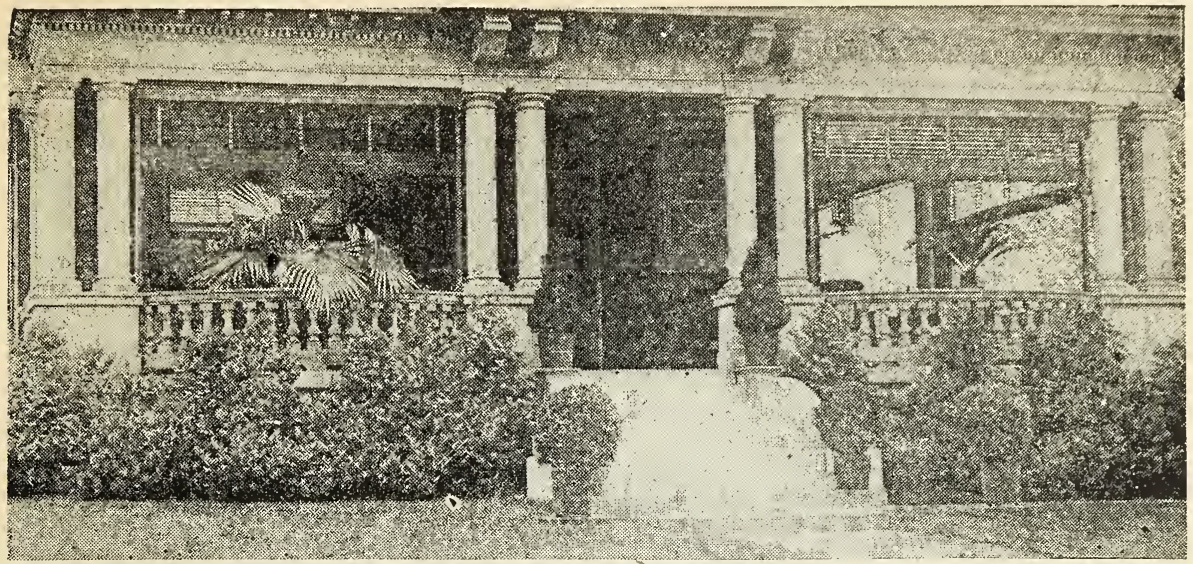

\section{EVERGREENS}

Our Evergreens are exceedingly well rooted and the more rare varieties are taken up with a ball of earth on the roots. We never advise planting Evergreens in the fall. We have recently added a line of the very rare and beautiful varieties, all of which are perfectly hardy, unless noted.

\section{ARBOR VITAE}

AMERICAN-A native variety, valuable for hedges. Stands shearing well.

HOVEYI-Compact, dense and conical with light yellowish green foliage.

GLOBOSA-Globe headed Arbor Vitae. Grows in a round globular form, very dense.

IUTEA (George Peabody) - Golden yellow, the entire season; grows in a pyramidal shape.

PYRAMIDAL-Grows in a beautiful pyramidal shape. Heavy, dark green foliage; the best evergreen for cemetery purposes obtainable.

ORIENTALIS (Chinese Arbor Vitae)-A beautiful dwarf growing, fine foliaged variety with a yellow tint. Needs a slight protection in severe winters.

\section{BUXUS}

BOX-The familiar evergreen shrub used for porch boxes and also for the yard. Needs light protection in the north in winter.

\section{FIR}

BALSAM OR AMERICAN SILVER-A very regular, symmetrical tree, assuming the conical form, even when young; leaves dark green above and silvery beneath.

\section{JUNIPER}

IRISH-A small tree or shrub of conical shape, very erect and dense. Desirable for cemeteries. CHINESE GOLDEN-Of pyramidal growth, with fine slender branches tipped with yellow.

JAPANESE GOLDEN-Rather dwarf spreading growth. Beautiful golden foliage of odd shape. Perfectly hardy. Very effective.

PFITZERIANA-One of the finest of the Juniper family. Graceful spreading branches, graceful in shape and fine in foliage.

SABINA-Of more spreading form, used much in rockeries.
SABINA TAMARISCIFOLIA-Another rare va riety with bluish green foliage.

SCOTTI (Scott's Cedar)-A beautiful light green, fine-foliaged tree growing in a pyramidal shape.

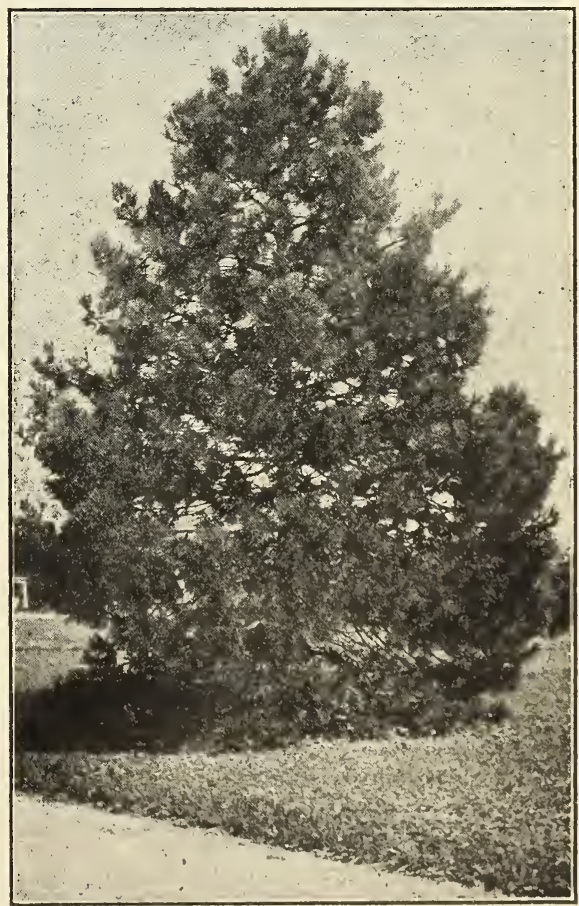

THE AUSTRIAN PINE 


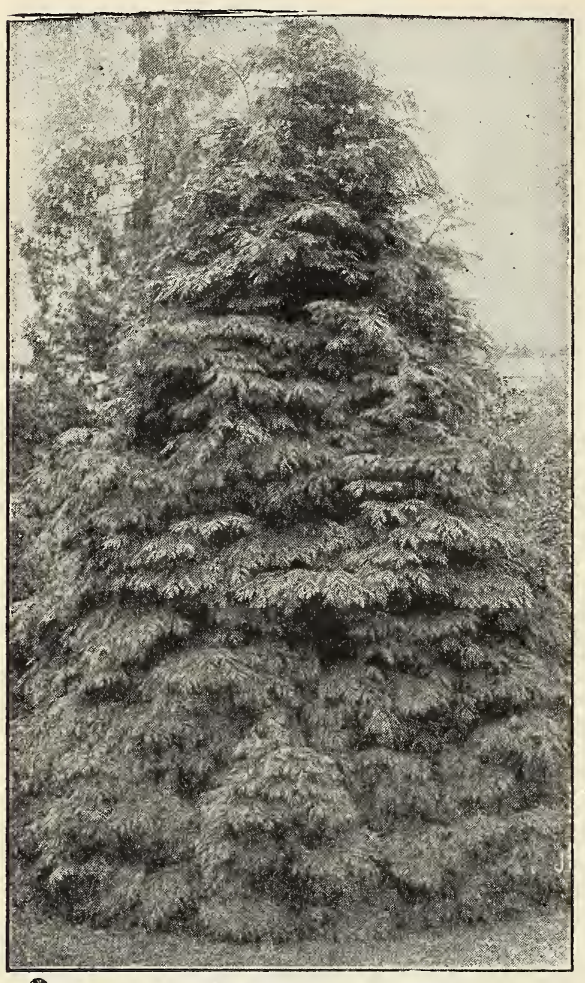

- A JAPANESE CYPRESS
PISIFERA FILLIFERA-An odd variety having drooping, thread-like branches.

\section{RHODODENDRON}

Rhododendrons are superb evergreen shrubs, producing dense clusters of magnificent flowers, but they require a somewhat shady situation and a peaty soil, free from lime. There are several colors the most attractive being white, red and purple, all of which we can supply.

OBTUSA-Beautiful, soft green, flat foliage.

OBTUSA GRACILIS-A neat, attractive and graceful variety with green foliage.

OBTUSA AUREA CRIPPSII-The most handsome golden variety we have ever seen. A bright golden yellow the entire season, with handsome slightly drooping foliage.

\section{SPRUCE}

COLORADO BLUE SPRUCE-A most heautiful variety discovered and disseminated from the Rocky Mountains; it is the barest blue of any evergreen; very distinct in foliage and growth; fine, compact habit. In great demand as a lawn tree throughout the eastern states where fine specimens are established proving it the best of all evergreen trees for the lawn. Fol. iage rich blue or sage color.

KOSTER'S BLUE SPRUCE-A particularlv blue colored Colorado Spruce now propagated by grafting. Imported.

HEMLOCK-Delicate, dark co!ored foliage, and drooping branches. Good for lawn and also makes a good hedge.

NORWAY - Of large and lofty appearance. Well adapted for large enclosures, and stands prun. ing well when used for hedges. It is exceeding. ly pieturesque and beautiful; very popular and deservedly so. We supply hundreds of these for Christmas every year.

SWEDISH-Similar to the Irish but more hardy. VIRGINIA GLAUCA-A beautiful and- graceful tree with cedar like foliage of a distinct silvery hue. The Blue Cedar, extra fine.

\section{PINE}

SCOTCH-A fine, robust, rapid growing tree with stout, erect shoots and silvery-green foliage. AOSTRIAN OR BLACK-A robust growing sort. Leaves long, stiff, dark green. Makes a large spreading tree.

WHITE-A native tree with light silvery foliage. The varieties of pines are especially valuable when tall windbreaks are desired. They are more rapid growing than most other evergreens.

MUGHO (Dwarf Mountain Pine) -A very broad spreading variety, yet always retains a symmetrical shape. Fine for planting on stony banks, slopes, etc. Grows 6 to 8 feet high.

PONDEROSA (Bull Pine)-A hardy and beautiful western variety with extra long needles.

\section{RETINOSPORA-JAPAN CYPRESS}

OBTUSA NANA-A dwarf form seldom growing over a foot high. Suitable for boxes or vases. Very rare.

OBTUSA NANA AUREA-A taller growing va. riety with odd yellow foliage.

PLUMOSA OR PLUME IIKE RETINOSPORA -A beautiful tree having flat, feathery foliage of a light green color; stands shearing well.

PLUMOSA AUREA OR GOLDEN CYPRESS-

The most popular of all golden evergreens. Has soft plume-like golden foliage which is particu larly bright in the spring.

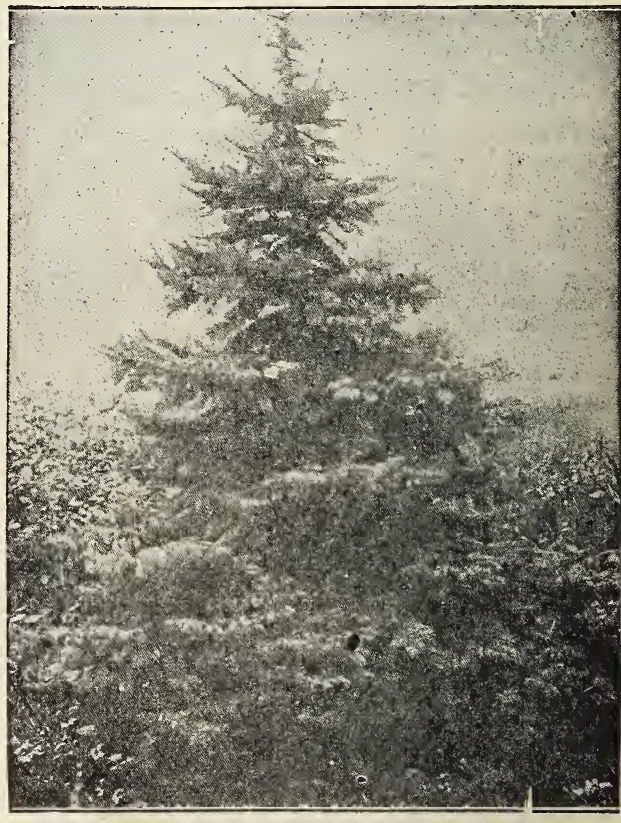

KOSTER'S BLUE SPRUCE 


\section{ORNAMENTAL SHRUBS}

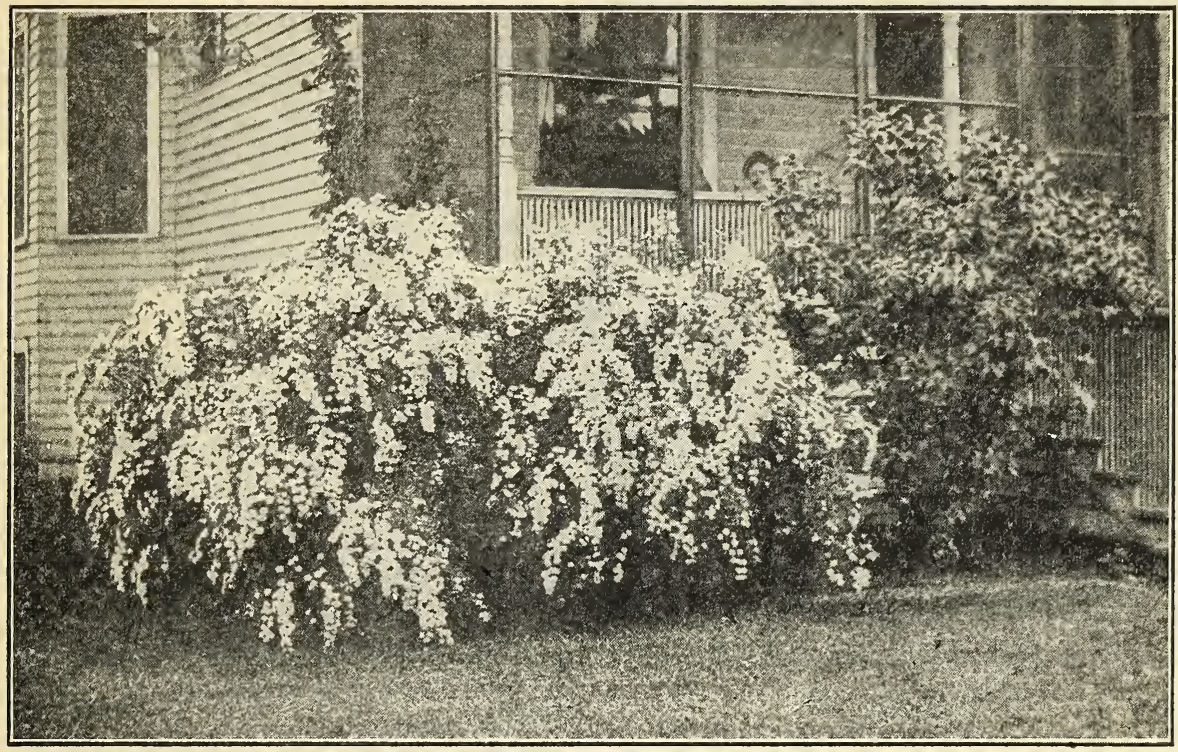

SPIREA VAN HOUTTE

\section{ALTHEA OR ROSE OR SHARON}

The altheas have a well-deserved popularity. They are free growers, and not particular as to soil. They bloom in August and September, when but few other sorts are in bloom. They attain a height of from six to ten feet. We can furnish double or single in a variety of colors.

\section{ARALIA}

PENTAPHILLA-Between a shrub and a tree, will grow 8 to 10 feet high; beautiful, more for its glossy dark green foliage and graceful habit of growth than for its flowers which are green in color.

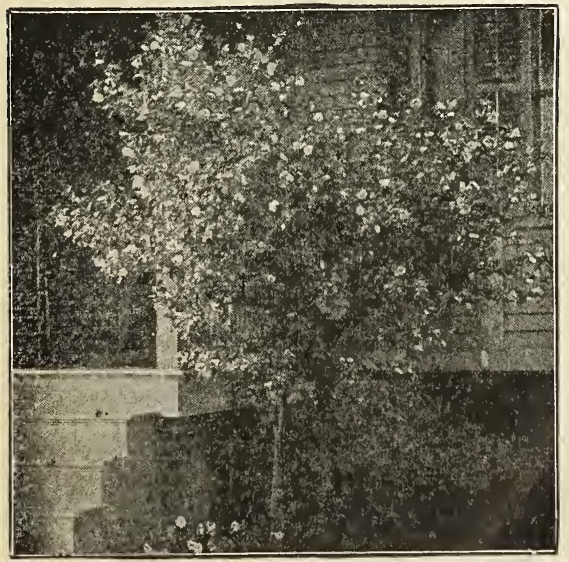

THE ALTHEA, ROSE OF SHARON

\section{AZALEA}

HARDY GHENT-This class of Azaleas are sufficiently hardy for open air culture and will stand our winters without protection, though a mulching of straw or loose litter is desirable, at least until they become established. They are among the most beautiful of flowering shrubs, presenting the best effect where massed in beds. They require a soil adapted to them to give good results. Like Rhododendrons they should have a sandstone soil and do not succeed on a lime stone soil.

MOLLIS-A splendid hardy species from Japan. One of the most valuable flowering shrubs. Flowers large and showy, like those of the Rhododendron, in fine trusses and of various colors.

\section{BARBERRY}

THUNBERGII-A most interesting and valuable shrub. Habit dwarf and spreading but delicate and shapely. Blooms in May, are white and a profusion of scarlet berries. Autumn foliage brilliant.

\section{BUDDLEIA VEITCHIANA}

BUTTERFLY BUSH OR SUMMER IILACOne of the most desirable Summer flowering shrub-like plants, beginning to bloom in July. The flowers are of a pleasing shade of violet mauve, and are borne in dense cylindrical spikes, which under liberal cultivation, are from 12 to 15 inches in length by 3 inches in diameter; it succeeds everywhere and flowers freely the first season planted, and is always admired. Tops die back to ground in winter.

\section{CALYCANTHUS OR SWEET SCENTED SHRUB}

Blooms in June, and at intervals through the summer. Flowers of a rare chocolate color; rich foliage. The wood and blossoms have a peculiar. ly agreeable flavor. Three to five feet high when fully grown. 


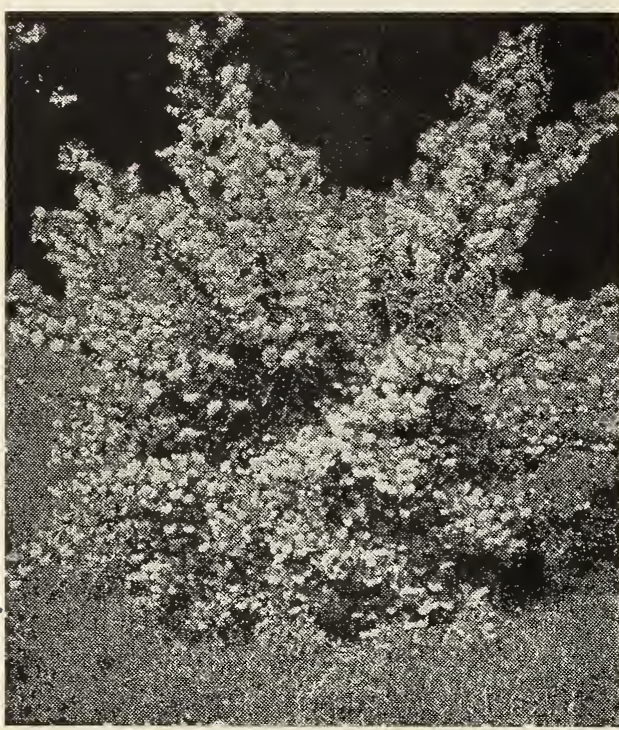

PRIDE OF ROCHESTER DEUTZIA

\section{CLETHRA}

ALNIFOLIA (Sweet Pepper Bush)-A handsome dwarf shrub, growing rarely over three feet. Blooms in August and September in spikes 3 to 6 inches long, white in color, and so fragrant as to perfume the air near by.

\section{CORNUS}

VARIEGATED LEAF-The flowers are bright yellow and are borne in clusters in early spring, before the leaves appear. The foliage is beautifully variegated with white. Makes small shrub. SIBERICA-Dark green foliage, pale on under side. Blossoms in early summer with numerous flat-topped clusters of creamy white, followed by fruit of light blue or bluish-white. Branches blood red, very attractive shrub.

\section{DEUTZIA}

The Deutzias are of Japanese origin, extremely hardy, luxuriant foliage, very attractive flowers and very fine habit. All things considered, they have but few equals for the lawn.

CRENATA-Double white flowers tinged with rose. Blooms the middle of June. Five feet high when fully grown.

GRACILIS-A graceful and charming shrub with pure white flowers. Blooms the middle of June. Two feet high when fully grown.

LEMOINE-An intermediate growing form with beautiful white flowers in clusters, covering the entire bush and blooming earlier than the other varieties.

PRIDE OF ROCHESTER-One of the finest varieties, producing large double white flowers, the back of the petals slightly tinged with rose. It excels all of the older sorts in size of flowers, profuseness of bloom and vigorous habit. Blooms early in June.

WELLSII-Another fine double white variety.

\section{EUONYMOUS}

RADICANS-VARIEGATA-A handsome Japan ese variety, growing almost as a vine instead of a shrub, trailing along the ground for a short distance; very low growing and extremely suit able for a low border. The leaves are variegated white and green, remain on almost all winter and are very striking.

\section{EXOCHORDA}

GRANDIFLORA (Pearl Bush)-A vigorous growing shrub from China, forming a compact bush 10 to 12 feet high; can be trimmed into any desired shape. The flowers are borne in slender racemes of eight to ten florets each, on light and wiry branches that bend beneath their load of bloom just enough to be graceful. It is perfectly hardy; flowers pure white. Very useful for cut flowers.

\section{FORSYTHIA}

Shrubs of about 6 to 8 feet in height. Very beautiful.

FORTUNEII-Growth upright, foliage deep green, flowers bright yellow. One of the best early flowering shrubs, the flowers appearing before the leaves. Hardy.

VIRDISSIMA-Twisted flowers, yellow with rich, shiny green foliage.

\section{FRINGE}

The Fringes are among the most popular and satisfactory large flowering shrubs. They are very hardy, do well in most any soil, and when in bloom they call forth universal admiration.

PURPLE-Also known as Purple Mist, Smoke Tree, and Smoke Plant. Covered during midsummer with loose panicles of curious hair or fringe-like flowers, giving it a mist-like and novel appearance.

WHITE-A superb shrub attaining a size of from ten to twenty feet. Has a compact, roundish form, large glossy leaves, and drooping racemes of pure white flowers. Blossoms in May and June. An entirely different plant from the above.

\section{HONEYSUCKLES}

BELLA ALBIDA-A tall shrub with great clus ters of fragrant white flowers, followed by red berries.

MORROWI-A spreading shrub with attractive white flowers, with brilliant red fruits in the fall. PINK TARTARIAN-A well known shrub; flowers light pink, which appear in May.



HONEYSUCKLE MORROWI 
RED TARTARIAN-Similar, but deep pink or WHITE TARTARIAN-Like the preceding, but has white flowers.

\section{HYDRANGEA}

The addition of the Paniculata Grandiflora has given the Hydrangea a high rank. Others of the new sorts are exceedingly beautiful and showy shrubs, but as they are not entirely hardy we cannot recommend them as highly as we can the Paniculata Grandiflora.

ARBORESCENS GRANDIFLORA-A grand addition to summer flowering hardy shrubs dwarfing the show of others in July and August by the magnitude and profusion of its flower heads. The flowers are, in a large way, similar to the familiar "Snowball" in appearance, and are so conspicuously white and imposing that whether as single specimens, as cut flowers, or in groupings, their presence is predominant.

PANICULATA GRANDIFLORA - Is absolutely hardy; thrives in all soils; grows rapidly and blossoms profusely. Flowers are pure white, afterward changing to pink, and are borne in large pyramidal trusses, often more than a foot long and six to eight inches in diameter. Begins to bloom early in August, and continues in bloom for several weeks. Wherever known, it is con. ceded to be one of the finest flowering shrubs cultivated. It is equally valuable for planting singly or massing in beds. We heartily commend it to all lovers of the beautiful. It will give great satisfaction. Attains a height of from three to five feet. Should be headed in every spring. Can be furnished in bush or trained into an upright tree form.

\section{JAPAN QUINCE}

One of the best known shrubs in cultivation. Very ornamental in early spring, as its bright scarlet flowers completely cover the branches be fore the leaves are formed. Makes a good hedge.

\section{KERRIA}

JAPONICA (Globe Flower) -A slender branched
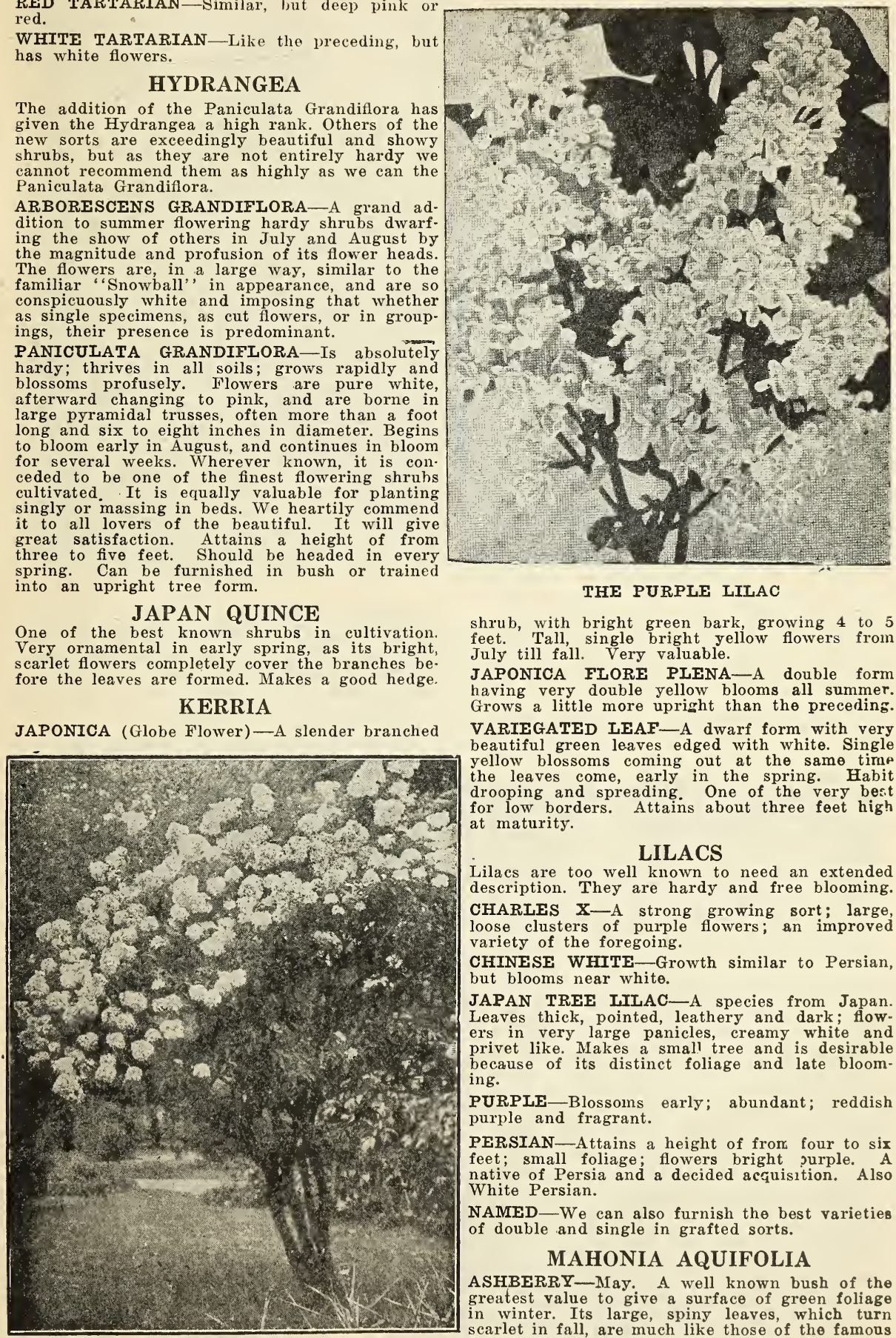

THE PURPLE LILAC

shrub, with bright green bark, growing 4 to 5 feet. Tall, single bright yellow flowers from July till fall. Very valuable.

JAPONICA FLORE PLENA-A double form having very double yellow blooms all summer. Grows a little more upright than the preceding. VARIEGATED IEAF-A dwarf form with very beautiful green leaves edged with white. Single yellow blossoms coming out at the same timp the leaves come, early in the spring. Habit drooping and spreading. One of the very best for low borders. Attains about three feet high at maturity.

\section{LILACS}

Lilacs are too well known to need an extended description. They are hardy and free blooming. CHARLES $\mathbf{X}$-A strong growing sort; large, loose clusters of purple flowers; an improved variety of the foregoing.

CHINESE WHITE-Growth similar to Persian, but blooms near white.

JAPAN TREE IILAC-A species from Japan. Leaves thick, pointed, leathery and dark; flow. ers in very large panicles, creamy white and privet like. Makes a small tree and is desirable because of its distinct foliage and late blooming.

PURPLE-Blossoins early; abundant; reddish purple and fragrant.

PERSIAN-Attains a height of from four to six feet; small foliage; flowers bright jurple. A native of Persia and a decided acquisition. Also White Persian.

NAMED-We can also furnish the best varieties of double and single in grafted sorts.

\section{MAHONIA AQUIFOLIA}

ASHBERRY-May. A well known bush of the greatest value to give a surface of green foliage in winter. Its large, spiny leaves, which turn scarlet in fall, are much like those of the famous English holly, and its bright yellow flowers in May are very effective. Good in shady spots 


\section{PRIVET}

Used chiefly for hedging, but the varieties we describe deserve prominent positions in the lawn as highly ornamental shrubs.

CAIIFORNIA-Of great value as a hedge, and of such positive beauty as to be attractive when grouped with other shrubs. When planted singly it forms a very compact, dense, upright shrub, of medium size. The leaves are so glossy as to have the appearance of having been freshly varnished. The foliage hangs on until late in the winter, making it nearly evergreen.

IBOTA (Chinese Privet)-A valuable new shrub, native of China and Japan. Flowers large, white, very fragrant, produced in great profusion; leaves long and shining; one of the hardiest of the Privets and distinct. A charming shrub which will be prized for its fragrant flowers, as well as for its handsome foliage. More hardy and taller growing than the California.

\section{SPIREA}

The varieties which we catalogue are exceedingly fine and interesting shrubs. They are hardy, easily grown, and as they bloom at different periods one may have flowers all summer by planting the entire list.

ANTHONY WATERER-A new dwarf compactgrowing shrub. Blossoms in broad, flat heads of beautiful deep red color. A perpetual bloomer. ARGUTA-A slender dwarf form growing 3 to 4 feet high. Blooms early in May, and forms a beautiful mass of snowy-white flowers.

BIILARDI-Blooms nearly all summer; rosecolored; fine feathery plume.

BIIIARDI ALBA - White flowers, large clus ters and bush grows 4 to 5 feet tall, similar to Billardi, but white.

CALIOSA ALBA-Dwarf. Of similar habit to the Anthony Waterer, but flowers are white.

CAIIOSA ROSEA-Desirable because it blooms nearly all summer. The flowers are rose-colored, borne in panicles. A very free grower.

FROEBELS-Dwarf, 2 to 3 feet. Flat heads of crimson flowers from June to September. Extra fine.

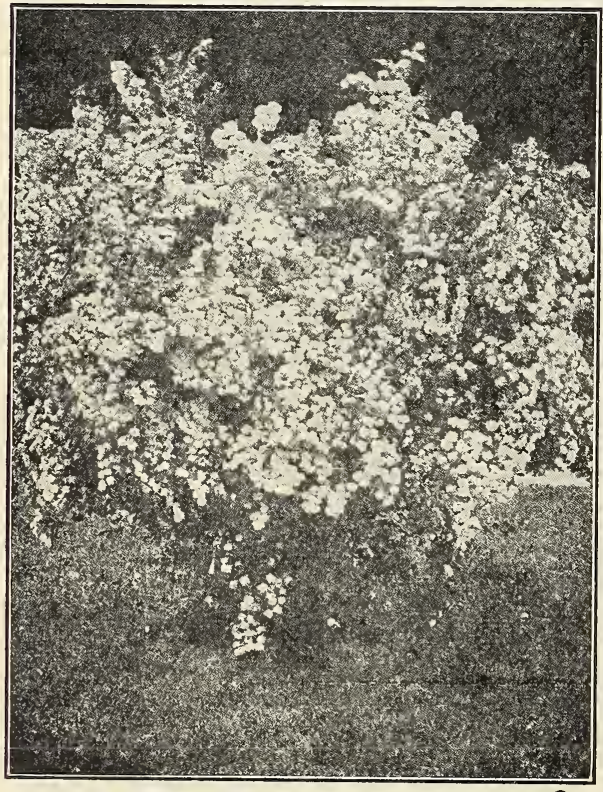

A SYRINGA OR MOCK ORANGE

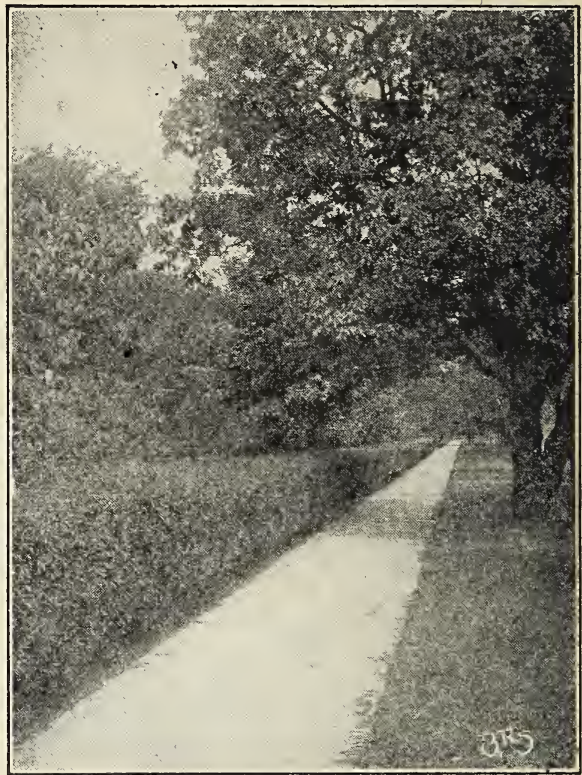

A PRIVET HEDGE

PRUNIFOIIA (Bridal Wreath)-The old-fashioned double flowered Spirea. Blooms very early, the long slender branches being covered nearly their entire length with small double flowers. Foliage a beautiful shiny green.

THUNBERG'S-A Japanese species of small size, with narrow linear leaves, and small white flowers; one of the best dwarfs.

VAN HOUTTEI-The finest of all Spireas, a most charming and beautiful shrub; having pure white flowers in clusters. Extraordinarily profuse in bloom, and the plant is a vigorous grower and very hardy.

\section{SNOWBERRY}

WHITE-A well known shrub with small, pink flowers and large, white berries that hang on the plant through part of the winter.

VUIGARIS-Red-fruited or Indian currant. A shrub of very pretty habit. Foliage, flowers and small fruit; fruit purple and hangs all winter.

\section{SYRINGA OR MOCK ORANGE}

GRANDIFLORA-Foliage bright green: tall growing pure white orange-like flowers in June. CORONARIUS (Garland Syringa)-A well known hardy shrub. White, fragrant flowers. Blooms in June. Makes a large shrub.

GOLDEN IEAVED-A small shrub of positive and striking beauty. The foliage is golden yellow, and retains its lovely color through the entire season. When set with other shrubs the contrast is very pleasing. White flowers. Blooms in June. Very hardy.

BOUQUET BLANC-The newest and best of all the Syringas. Bound to rank with the Spirea Van Houttei, when it becomes known, and as showy as the latter, when in bloom. Flowers pure white with a semi-double appearance and completely covering the bush with a mantle of graceful beauty. The most sweet scented of any Syringa that we have ever seen. Bush remains in bloom for several weeks. The best of the new introductions.

\section{TAMARIX}

AFRICANA-Of tall, slender, upright growth 


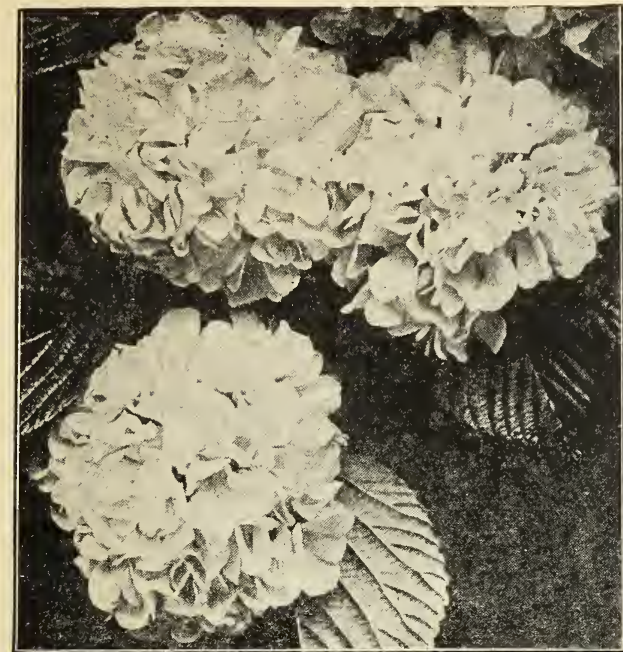

THE JAPANESE SNOWBALL

with feathery, asparagus-like foliage. Beautiful green appearance. Bright pink flowers in racemes in May. Dark reddish-brown.

\section{VIBURNUMS OR SNOWBALLS}

OPULUS (High Bush Cranberry)-Eight to ten feet high; foliage lustrous green, changing to rich copper; blossoms in May with white flowers in flat-topped clusters, followed by scarlet fruit. PLICATOM OR JAPAN SNOWBALL-Handsome plicated leaves; globular heads of pure white neutral flowers, early in June. It sur. passes the common variety in several respects. Its habit is better, foliage much handsomer, flow. ers whiter and more delicate. One of the most valuable flowering shrubs.

STERILIS (Common Snowball)-A popular shrub. Makes a large bush. Bears balls of pure white flowers in June.

\section{WEIGELIA}

Of Japanese origin, producing in June and July superb, trumpet-shaped flowers of various colors, from the purest white to the richest red; very ornamental in the fall.

CANDIDA-Is of vigorous habit, an erect grower becoming in time a large sized shrub; flowers pure white and produced in great profusion in June and the plants continue to bloom during the summer.

EVA RATHKE-New. One of the best of the Wegelias, the plants having a vigorous habit and bearing freely well-shaped, large, crimson red flowers. Blooms several times during the season.

ROSEA-The best known sort. From China. Rose-colored, trumpet-shaped flowers. Blooms in June. Four to six feet.

VARIEGATED IEAVED-Leaves bordered with yellowish white, making the bush very conspic. uous the entire season. Pink flowers blooming in June. A very desirable shrub.

In Shrubs we pursue the same policy as we do in fruits, viz: to offer only those which we have known to succeed and those which we consider as hardy in this latitude. We test many new ones each year as they are offered and if they meet our requirements in a shrub we adopt it permanently and offer it for sale. We now have a business in landscape work that requires thousands of shrubs each year. We will prepare planting plans and estimates when desired. Our Shrubs will be found especially well rooted as our soil produces an abundance of fibrous roots.

\section{HARDY CLIMBING VINES}

Ornamentals of this class are so hardy, so easily grown, and so beautiful that they deserve greater attention than they receive. No artist can produce pictures equal to the wealth of beauty displayed by the elegant Wistaria, the graceful honeysuckle, or the charming and magnificent clematis when in the glory of full bloom, and there is nothing in art that will in any degree compare with the gorgeous hues of the Ampelopsis after it assumes its brilliant autumual tints.

\section{AMPELOPSIS VEITCHII}

BOSTON IVY - Leaves a little smaller and more ivy-like in form than foregoing. Overlapping each other they form a dense sheet of green. The plant requires a little protection the first winter until it is established, but after that it may be safely left to care for itself. It grows rapidly and clings to the surface of even a painted brick wall with great tenacity. Foliage changes to orimson scarlet in autumn.

\section{ARISTOLOCHIA}

DUTCHMAN'S PIPE-A rapid growing vine, with magnificent foliage, ten to twelve inches in diameter, and curious pipe-shaped, yellowishbrown flowers.

\section{HONEYSUCKLE}

AUREA RETICULA-Strong in growth and the leaves are filled with a network of golden veins, giving the entire vine a beautiful golden appearance. Flowers creamy white.

CHINESE TWINING-A well known vine holding its foliage nearly all winter. Blooms in July and September and is very sweet.

HALL'S JAPAN-A strong, vigorous evergreen variety, with pure white flowers changing to yellow. Very fragrant; covered with flowers from June to November.

MONTHLY FRAGRANT-Blooms all summer.
Flowers red and yellow. Very sweet.

\section{WISTERIA}

CHINESE PURPLE-One of the most elegant climbing vines known, and a verp rapid gower after it gets thoroughly es tablished, some t i m e s making twenty feet of wood in a sin gle season. Bears long chus ters of pale blue flowers in May and June, and also in September. Extremely hardy. Attains a larger size than any other cilmber.

Also $\mathrm{Ch}$ in e se White, a white form of the above.

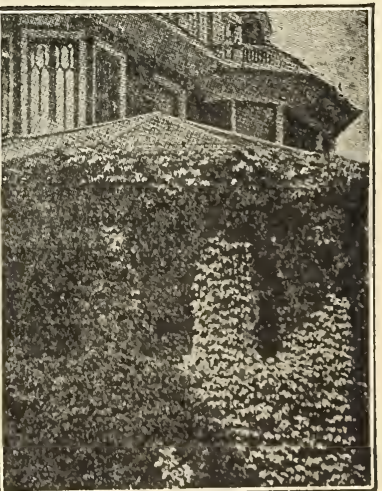

BOSTON IVY 


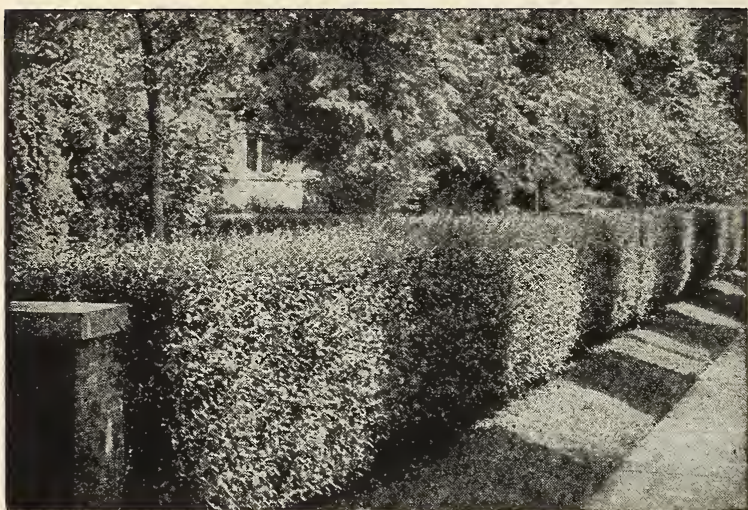

AN LVLRGRLEN HEDGE

\section{CLEMATIS}

HENRYII-Fine blooiner; flowers large, of a beautiful creamy white, consisting generally of from six to eight petals. June to October.

JACKMANNI-This is the variety upon which Mr. Jackman bestowed his name. It is better known than any other, and still stands as one of the best. It is a strong grower and produces a mass of intense violet purple flowers from June to October.

VILLE DE LYON-Flowers large, of a beautiful bright velvety red, very free flowering and con tinous bloomer. The best red Clematis that we know of.

PANICUIATA - A great novelty from Japan. One of the most de sirable, useful and beautiful of hardy garden vines, a luxuriant grower, profuse bloomer, with fine foliage Flowers medium size, very fragrant, produced in the greatest profusion in late summer.

RAMONA-A new American seedling Clematis. It is a free and perpetual blooming variety, both on the old year's growth and also on the wood of the current year; the color of the flower is a deep sky blue, and very attractive; the size of the flower is larger than any va. riety we ever saw, very many flowers running from five to seven inches in diameter.

\section{HEDGE PLANTS}

AMERICAN ARBOR VITAE-Forms a very handsome ornamental hedge of fairly dense growth.

BARBERRY, Japan Quince and Rugosa RosaAll make fine untrimmed hedges.

NORWAY SPRUCE-With careful pruning may be kept low and in good shape, and grown in this shape is highly ornamental.

PRIVET, California or Ibota (Chinese)-Are the leaders in hedges.

SCOTCH PINE, Austrian Pine, American Arbor Vitae-All well adapted for planting in belts for windbreaks.

\section{ROSES}

After years of experimenting we are now handling Roses (except part of the climbers), which are imported direct from Holland. They are superior to those produced by the growers of Roses in this country because they have vastly better roots and better tops. We carry one of the most complete lists of Roses, including all the new leading varieties which give promise of success. So many new Roses are constantly being introduced that we cannot list all of them. We list only the long tried and the very best of the new sorts.

NEW AND RECENT INTRODUCTIONS

FLOWER OF FAIRFIELD (New)-The really everblooming Crimson Rambler long sought by rose growers. It carries the crimson splendor of the type from spring even into November; commencing to bloom on the first young, red shoots and adding size and brilliancy with its growth; an important acquisition.

BABY RAMBLER-A dwarf (bush, not climbing) form of Crimson Rambler, and furthermore, everblooming. Will bloom continuously throughout the summer if planted out-of-doors. Has the same bright crimson color as the Climbing Crim. son Rambler, and blooms in clusters of 20 to 40 flowers at one time on plants of fair size. It is one of the best red roses for bedding and is going to be just as popular and as extensively planted as the climbing form has been. May be grown in pots and bloom with ordinary treatment from one year's end to another. The best rose novelty of recent years. It is perfectly hardy.

FRAU KARI DRUSCHKI-The white American beauty. A new white hybrid perpetual rose. This is an ideal hardy white rose, a healthy, vigorous grower, large, perfect in form', snow white in color, very free flowering. Large, field grown plants. White and pink Baby Ramblers. Similar to the above in every way except in color. SOLIEL D'OR (Golden Sun)-The most unique rose in cultivation, being the first of a new race. A strong, robust grower, with straight branches, and heavy, deep green foliage. The color of a fully expanded flower is extraordinary and is not found in any other variety in cultivationa blending reddish-gold, orange-yellow, forming

a combination that is well described when the

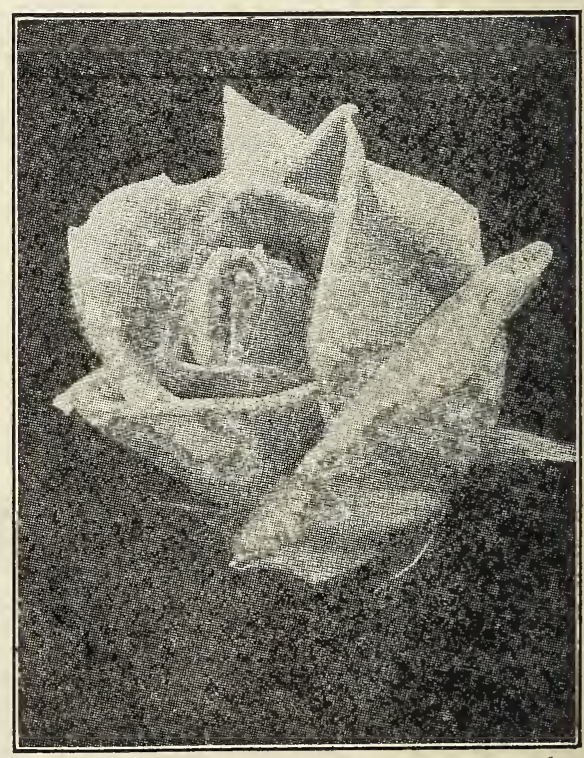

FRAU KARL DRUSCHKI 
rose was named Golden Sun, and no description can do justice to the peerless beauty of this wonderful, new, hardy yellow rose. It will prove hardy in all sections of the country. Wherever shown this rose has won all first prizes. It has but one drawback to the propagator's mind, and that is that it does not succeed well on its own roots, and we therefore offer it in strong, low budded plants, two year stock only.

Also Blue Rambler and other new novelties.

\section{HYBRID PERPETUAL ROSES}

With the care noted above these Roses will produce a succession of bloom from June till frost, produce new wood constantly and the bloom is assured. They are perfectly hardy and will endure the winter unprotected; but will produce a great abundance of early flowers if somewhat pro. tected. 'They should be severely pruned in the spring before the buds start.

ALFRED COLOMB-Bright carmine red; clear color, large, deeply built form; exceedingly fine. AMERICAN BEAUTY-This valuable rose is of American origin, being introduced by a Washing. ton florist. It is equally valuable for forcing or open air culture. The flowers are a deep crim. son color, of very large size, and the most fragrant of its class. It is a continuous bloomer. Should be protected in winter.

ANNE DE DIESBACH-Brilliant, crimson, sometimes shaded with bright maroon. A superb garden sort; fragrant; one of the hardiest and best.

BARONNE DE BONSTETTEN-Rich, dark red, passing to velvety maroon; highly fragrant. Very double.

BARONESS ROTHSCHILD-Light pink, cupped form, very symmetrical; without fragrance; very beautiful. A moderate grower only.

CLIO-New. Flesh color shaded in center with rosy pink. Flowers large, of fine globular form; handsome foliage, one of the handsome new roses.

GENERAI JACQUEMINOT-Brilliant crimson, large and very fine, one of the handsomest and most showy roses of this color. Beautiful in the bud; semi-double when full blown. Of fine, free growth; a universal favorite.

LA FRANCE-Delicate silvery rose; very large and full; an almost constant bloomer, equal in delicacy to a Tea rose; the most pleasant fra. grance of all roses; a moderate grower; semihardy.

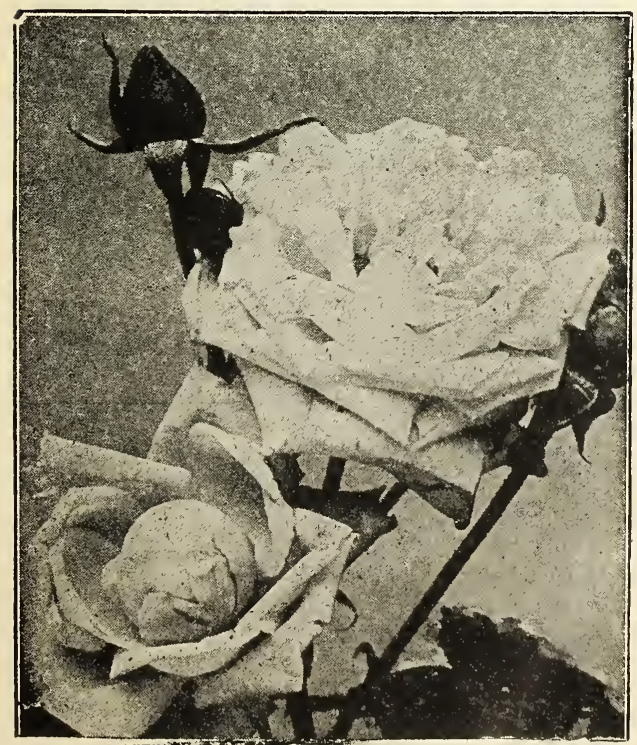

IA FRANCE

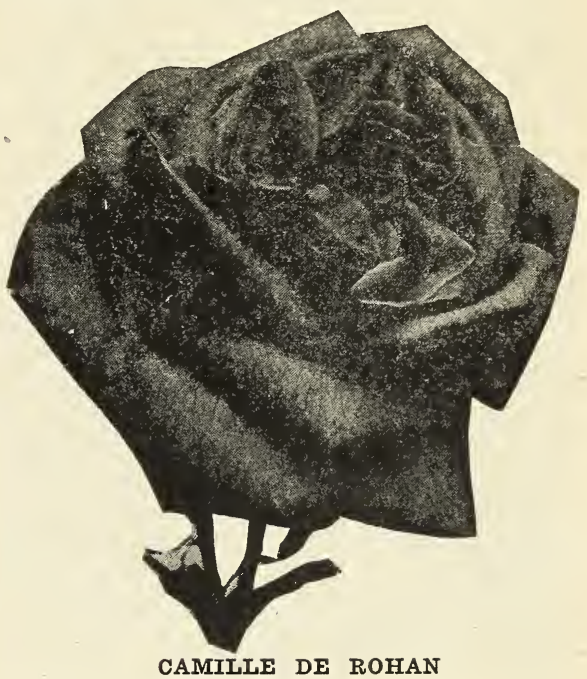

MABEL MORRISON-A sport from Baroness Rothschild. White, changing to pure white, in the autumn tinged with rose; double cup-shaped flowers, freely produced. In all, save substance of petal and color, this variety is identical with Baroness Rothschild.

MADAME CHARLES WOOD-The flowers extra large, full and double; color deep rosy crimson, sometimes brilliant scarlet with maroon shading; a constant and profuse bloomer.

MADAME GABRIEL LUIZET-A magnificent pink rose; has often been awarded the first premium at rose exhibitions; very large, and possesses a pleasing fragrance. Known as Hardy La France which it resembles.

MAGNA CHARTA-Bright pink, suffused with carmine; very large, full and fragrant, with magnificent foliage. A free bloomer.

MARGARET DICKSON-Of magnificent form; white, with pale flesh center; petals very large, shell shaped, and of great substance; fragrant, a fine variety; foliage very large, dark green.

MARSHALL P. WILDER-New, color cherry carmine; continues in bloom long after other $v a$ rieties are out of flower; the finest $H$. P. rose yet produced.

MRS. JOHN LAING-A seedling from Francois Michelon; soft pink; large and of fine form produced on strong stems; exceedingly fragrant one of the most valuable varieties for forcing. and flowers continuously in the open ground. Most beautiful rose of recent introduction.

PAUL NEYRON-Deep rose color; good foliage by far the largest variety in cultivation. Probably the best bloomer in the entire list. An especially satisfactory variety to plant.

PRINCE CAMILLE DE ROHAN-Deep velvety 
crimson, large, moderately full. A splendid rose. ULRICH BRUNNER-Raised from Paul Neyron. Brilliant cherry red, a very effective color; flow: ers of fine form and finish, carried well upon the plant; petals of great substance; plant vig- orous, hardy, and resists mildew. One of the best varieties for forcing and open air culture. A strong growing variety.

VICTOR VERDIER-Clear rose, globular, fine form and free bloomer; superb.

\section{CLIMBING ROSES}

BALTIMORE BELLE-Fine, white with blush center; very full and double.

CRIMSON RAMBLER-This wonderful rose has been thoroughly tried and in all situations has proved all that could be claimed for a new in. troduction, and it has far surpassed all that was hoped for it. As a climbing or running rose it has no equal. The foliage is rich, dark green, the growth rapid and diverse, but its great beauty is when the plant is covered with a profusion of the brightest crimson, partly doubled flowers which remain on a long time, thus prolonging the term of its magnificence. By far the best climbing rose.

CLIMBING AMERICAN BEAUTY-New. This new climbing form of the famous pink Rose, so long the American favorite for cutting, is as lovely and fragrant and deeply pink as the bush form. The hardy climber blood with which it is crossed, gives healthy, perfect foliage and a strong climbing habit of growth; the abundant bloom being prime before the June show of the bush type.

DOROTHY PERKINS-This is a splendid shellpink Climbing Rose with a bloom unequalled by any other variety unless it is the Crimson Rambler. This new rose is of the same strong habit of growth as Crimson Rambler, and the flowers are borne in clusters of 30 or 40 and sometimes even 50 to 60 . The flowers are large for a rose of this class, very double, sweetly scented and of a beautiful shell pink, a color that is almost impossible to accurately represent by lithography.

EXCELSA (Red Dorothy Perkins)-A radiant blood-red cluster rose, as free and double as Dorothy Perkins of which it is the red prototype. The clusters are very large and fairly cover the vines.

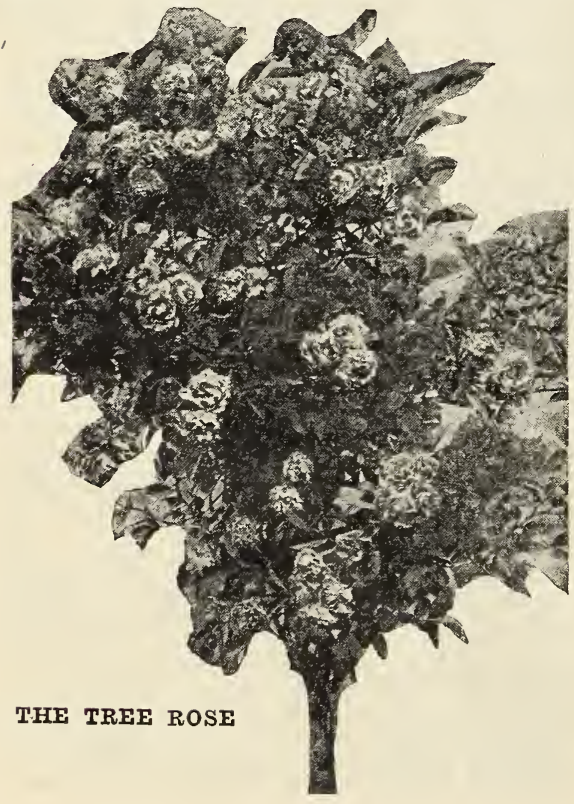

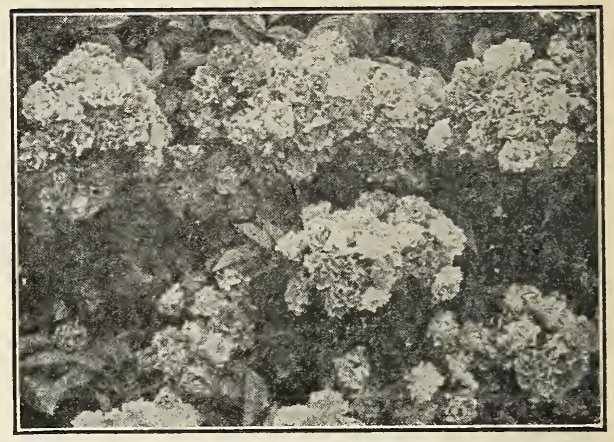

CRIMSON RAMBLER

PINK RAMBLER-Possesses the same valuable features found in the White Rambler, with which it differs only in color, which is a brilliant light carmine; not as good a bloomer as the Crimson Rambler.

QUEEN OF THE PRAIRIE-Bright rose color, large, compact, globular; and a very profuse bloomer. One of the best.

SEVEN SISTERS-Large clusters of bloom, shaded to dark red.

TAUSENDSCHON (Thousand Beauties)-A rapid growing, almost thornless climber, showing the blood of Rambler, Polyantha and Tea parentage. Its innumerable flower clusters make a pretty show through June and July; at first, the soft pink of Clotilde Soupert, and later deep. ening to a bright carmine rose.

WHITE DOROTHY - A beautiful white flowered cluster rose, as free and expressive as its pink rival, the Dorothy Perkins. The vines are a sheet of white during their blooming season and are especially valuable because of the rarity of good white Climbing Roses.

WHITE RAMBLER-Flowers are the size of a silver dollar, perfectly filled, very fragrant. Color pure white, sometimes tinged with blush. Blooms in clusters; rather tender and not a very good bloomer.

YELLOW RAMBLER-A new climbing rose of class and habit of the famous Crimson Rambler; flowers medium size, cup shape, nearly full, sweet scented; blooms in large clusters; color very light yellow; tender; not a very good bloomer.

\section{MOSS ROSES}

We can furnish Moss Roses in white, pink, red.

\section{RUGOSA ROSES}

For an untrimmed hedge and for planting in masses in shrubbery the Rugosa Roses are un. surpassed. They have the finest foliage of all Roses; their large and abundant single pink or white flowers are lovely, and the large and showy red fruit that follows the flowers make them very attractive until severe freezing weather comes in the winter.

\section{TREE ROSES}

These are grafted on tall stems of the Dog Rose, forming a half weeping head three or four feet from the ground. They can be furnished by colors only. Order by color only. 


\section{HARDY PERENNIAL PLANTS}

The habit of using hardy plants that do not have to be taken up each fall is spreading rapidly and the demand for them is constantly increasing. To supply that demand we have been increas. ing our plantings of them each year. We now devote a considerable space to Perennials and can offer the very best that there is on the market. We list the leading hardy plants below, but we have many others in small supply and are constantly adding to this list each season. Price, for field grown clumps, $15 \mathrm{c}$ each; $\$ 1.50$ per dozen, unless noted otherwise.

\section{ACHILLEA}

BOULE DE NIEGE (Ball of Snow)-A new form of this valuable perennial, more erect and compact than the Pearl, with fuller ball-shaped flowers; pure white.

\section{ANEMONE JAPONICA (Wind Flowers)} ANEMONE JAPONICA (Wind Flowers)-A most valuable class of hardy plants suitable for edging massing or single specimens. They grow rapidly 2 to 3 feet and are profuse in bloom, gaining strength and beauty each year. The blooming period extends from August till mid-November, the large open flowers furnishing abundant cut-flowers and a brilliant field display.

ALBA-Purest white, with yellow center.

QUEEN CHARLOTTE-Flowers semi-double, broad and perfectly formed of that pleasing shade of pink found in La France rose.

RUBRA-Showy rose-color, yellow center.

WHIRLWIND-Excellent double white flowers, 21.2 to 3 inches across.

\section{AQUILEGIAS OR COLUMBINES}

The Columbines are one of the most elegant and beautiful of hardy plants, and usually make themselves at home in any hardy border. Their period of flowering covers late spring and early summer months. As a whole they are most im-

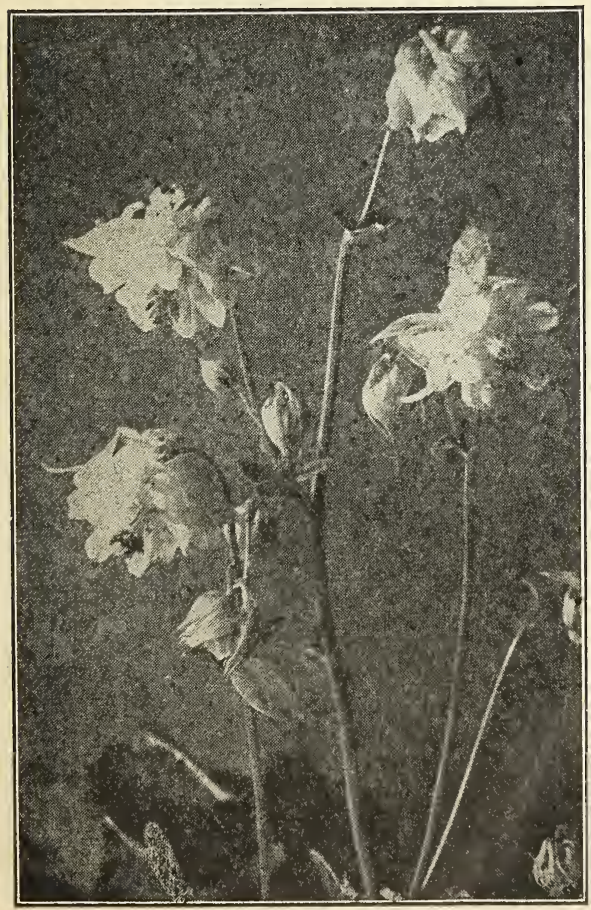

THE COLUMBINE

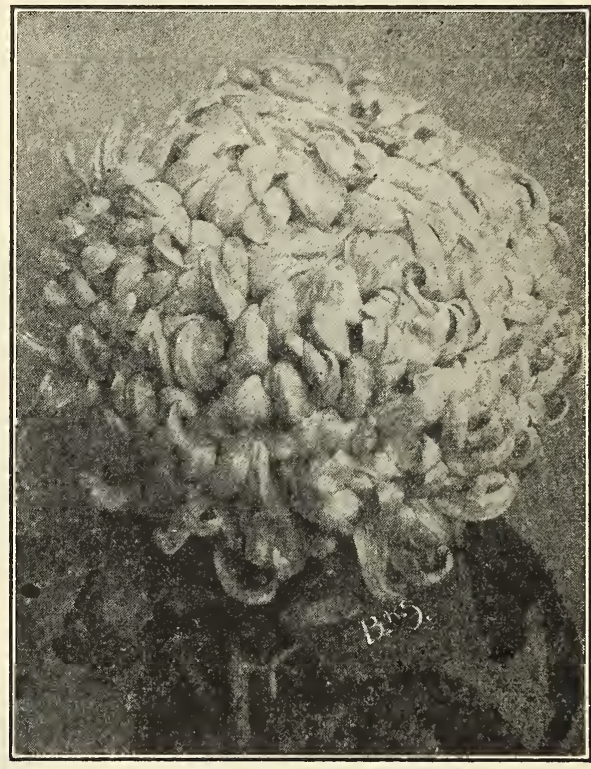

CHRYSANTHEMUM

portant part of the hardy garden, and should be grown in quantity by every lover of old-fash. ioned garden flowers. Mixed colors, 15c; separate, $20 \mathrm{c}$.

COERULEA (Rocky Mountain Columbine)Bright blue and white long-spurred flowers. CHRYSANTHA-Yellow, long-spurred flowers.

\section{BOLTONIA}

BOLTONIA IATISQUAMA-Tall, 4 feet or more in height, with aster-like lavender pink flowers in broad heads during August and September. A handsome plant for borders and masses.

\section{CAMPANULA (Canterbury Bells)}

C. CARPATICA (Carpathian Harebell) - A very pretty species, growing in compact tufts, not $\theta x$ ceeding 8 inches in height; flowers clear blue, one inch in diameter; from June to August.

CALYCANTHEMA ("Cup and Saucer")-Most popular form of Canterbury Bells. Cup-shaped flowers 3 inches long, set in saucer-like calyx 3 to 4 inches across; entire flower of one color. Very productive. We offer three separate colors, blue, pink and white.

\section{CHELONE (Turtle Head)}

LYONII-A beautiful perennial for massing. glossy green foliage, with spikes of bright red flowers, blooming through August and September.

\section{CHRYSANTHEMUMS}

Large flowering, hardy, old-fashioned. The fragrant old-fashioned kind that you have seen 


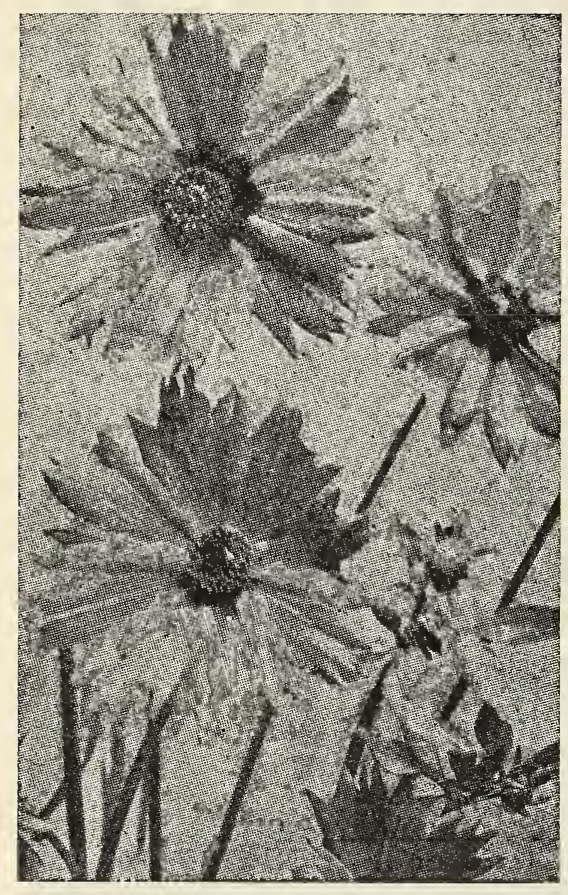

THE GALIIARDIA

alongside the farm house and in the old-fash. ioned garden.

GOLDEN QUEEN-Yellow.

BRIDESMAID-Pink.

EXCELSIOR_Bright yellow pompom.

INDIAN-Red.

ST. ALMO-White.

SOIIEL D'OR-Orange, pompom, but good size. VICTOR-Rosy crimson.

\section{CLEMATIS (Shrubby Clematis)}

Shrubby, erect garden plants from 2 to 4 feet tall, blooming very freely during August and September, with dainty tubular flowers.

C. DAVIDIANA-Delicate, lavender-blue; very sweet.

\section{COREOPSIS (Grandiflora)}

A beautiful hardy border plant that grows 15 to 18 inches high and produces its bright golden yellow flowers in great profusion the entire sea. son. Beautiful masses and a favorite for cutting.

\section{DELPHINUM (Larkspur)}

BELLADONA-A magnificent new Larkspur, surpassing every other variety in delicacy of color and freedom and continuance of bloom. Flowers are an exquisite shade of turquois-blue, commencing to show in June and continuing until frosts.

FORMOSUM-A strong, robust perennial, 2 to 3 feet high; flowers in abundance; dark blue with white center. June and July. If the flower-stalks are cut down immediately after the first blooming, another crop of flowers can be obtained in autumn.

BELI.AMOSA-Dark blue, combining the color of the Formosum and the good qualities of the Belladonna.

\section{DIANTHUS (Hardy Pinks)}

Valuable border plants, hardy everywhere and blooming freely in May and June. All have a rich clove fragrance. We offer several distinct Hardy Garden Pinks.

\section{DICENTRA}

SPECTABILIS (Bleeding Heart)-Rosy red, heart-shaped flowers in drooping racemes; early spring. Two feet. 20c; $\$ 2$ per doz.

\section{DICTAMUS}

ALBA (Gas Plant)-Fragrant aromatic foliage giving off a vapory gas when bruized. Spikes of pretty curious white flowers.

FUNKIA

DAY LILY-White or blue, 10c each; \$1 per 12. GAILLARDIA

GRANDIFLORA-This is considered one of the most beautiful and desirable plants in cultivation, beginning to bloom in June; they continue one mass the entire season. Base of petals are scarlet crimson, bordered golden yellow. A most beautiful combination. This is the true Grandiflora grown from divisions.

\section{HIBISCUS}

MEEHAN'S MALLOW MARVELS-A magnifcent new strain of hardy Mallows, which for size and profusion of bloom and richness of col. oring are among the most striking and beautiful perennials that grow. Flowers 8 to 10 inches in diameter ranging in color through various shades of red, pink and white. Separate colors, 30c each, $\$ 3$ per doz.; mixed colors $25 \mathrm{c}$ each; $\$ 2.50$ per doz.

\section{HEUCHERA BRIZOIDES}

CORAI BELLS-Coral pink, extra fine. Tall stems, blooming most all summer.

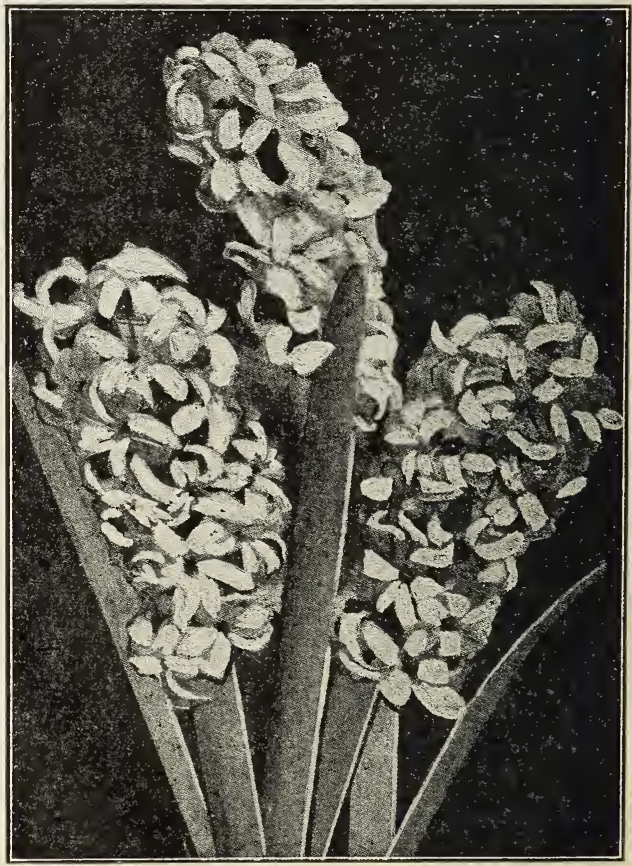

THE HYACINTH 


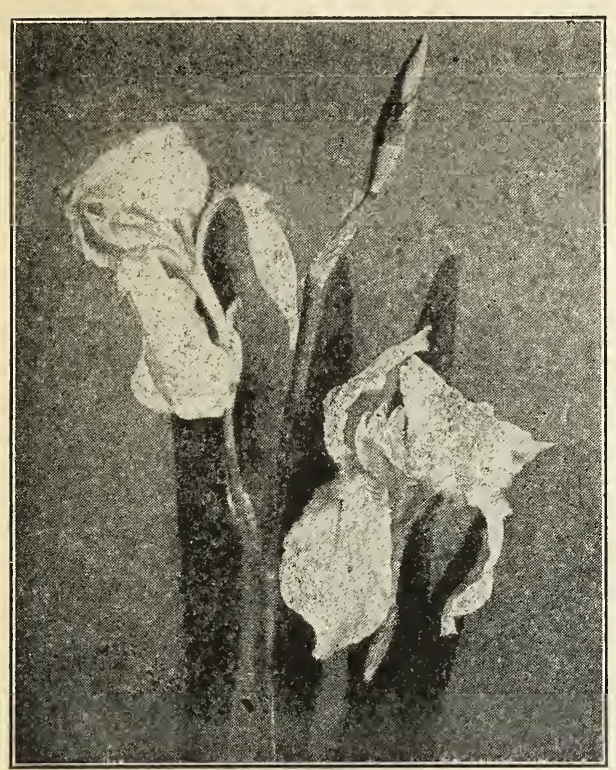

JAPAN IRIS

German or Orchid-Flowered Fleur de Lis, blooms in May and June. 10c each; $\$ 1.00$ per dozen. ALBERT VICTOR-Deep blue.

CANARY BIRD-Falls creamy white, uppers light canary-yellow; medium sized flowers.

CELESTE-Falls bright blue, uppers delicate grayish blue; all having a levender effect.

CHERION-Pinkish, falls streaked with red, nearest red iris.

DARIUS-A pleasing shade of yellow, falls blue. FLORENTINE ALBA-Very early, large white. HONORABLE-Golden yellow standards, falls rich crimson brown.

IVORINE-Very large, extra early white.

JOHAN DEWITT-Standards bluish violet; falls deep violet purple veined with white.

MAD. PAQUETTE-Reddish purple.

PALLIDA ALBERT VICTOR-Very large late light lavender blue. Exceptionally fine. Tall.

ORIENTALIS SNOW QUEEN-An exquisite hardy Iris; flowers of a snowy whiteness, large and well formed, produced in great abundance. Foliage light and graceful. A gem for flower border or waterside, 2 to 3 feet high. $10 \mathrm{c}$ each; $\$ 1.00$ per dozen.

IRIS SIBERICA-Purplish blue, 3 feet high, very desirable. June. $10 \mathrm{c}$ each; $\$ 1.00$ per doz. IRIS PSEUDO ACORUS-Bright yellow. May and June. Does best in wet places. 10c each. $\$ 1.00$ per dozen.

JAPAN IRIS-Finest of all the Iris family. The flowers are of immense size, from six to eight inches in diameter, and of the most beautiful and delicate shades. They are perfectly hardy, and flower in great profusion during June and July. A well established plant gives a dozen or more flower stalks two to three feet high, each stalk producing two to four enormous blooms.

Order by color only, Royal Purple, Mottled Blue, Lavender, White, all 25c each; $\$ 2.50$ per doz. LIATRIS (Blazing Star or Gay Feather) Very showy and attractive, succeeding any. where, producing long spikes of rosy purplish flowers from July till fall. Spikes three to four feet high.

\section{LYCHNIS}

CHALCEDONICA-A most desirable plant, heads of brilliant orange-scarlet, grows 2 to 3 feet high and blooms all summer.

VISCARIA, DOUBLE RED-Form a dense tuft of evergreen foliage, and in June sends up spikes of handsome, double, deep red, fragrant flowers remaining in perfection for six weeks. June and July.

\section{MONARDA DIDYMA}

CAMBRIDGE SCARLET-Bushy, coarse-leaved plant, growing about two feet high; covered with round, full heads of red flowers. The Mon. erdas are well known as "Bergamot," "Os. wego Tea," "Mint," etc., on account of the delicious fragrance of their leaves when crushed, this particular variety being an exceedingly showy scarlet and one of the freest blooming hardy plants of any color.

\section{LINUM}

PERENE-Foliage is fine and graceful, with flowers shaped like those of Phlox. Blooms all summer. Clear delicate light blue.

\section{ORNAMENTAL GRASSES}

EULALIA GRACIIIS UNVITATA-This plant is of most graceful habits and is very useful for decorating purposes. The best ornamental grass in cultivation.

EULALIA JAPONICA ZEBRINA (Zebra Grass) -Leaves crossed every two or three inches by a band of yellow half an inch wide.

EULALIA JAPONICA VARIEGATED-Long, narrow leaves, striped with green and white.

\section{PYRETHRUM HYBRIDUM}

PAINTED DAISIES-Red, white and pink, blooms in June and July; a most beautiful, hardy plant. Long season of bloom.

\section{PLATYCODON}

GRANDIFLORUM (Balloon Flower)-Blooms

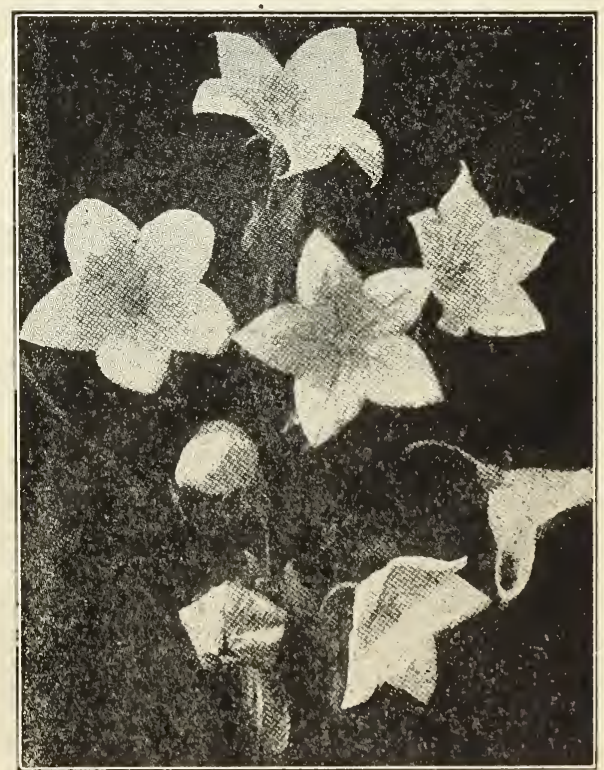

PLATYCODON 


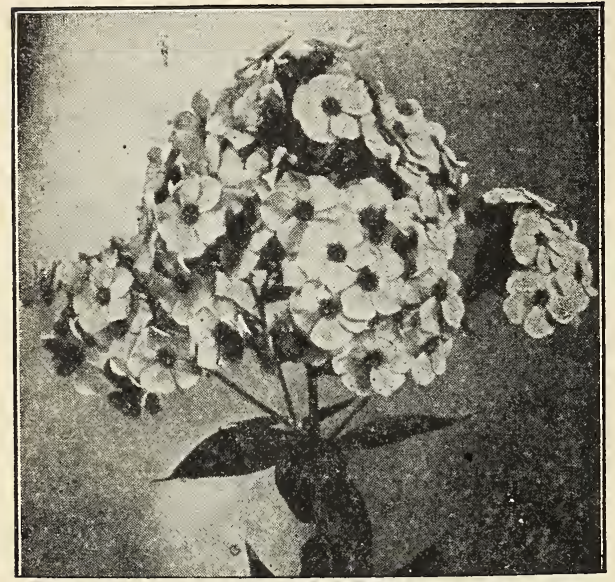

HARDY PHLOX

constantly from July until late in September; flowers large, bell-shaped, of a deep shade of blue. An extremely rapid grower, making a dense branching bush two to three feet high. ALBA-Saine as Grandiflorum, except white.

\section{PERENNIAL PEA}

Red, pink and white. July till frost.

\section{HARDY POPPIES}

Among the most welcome flowers, that glorify the early spring and summer are the big- glow. ing, nodding Poppies.

PAPAVER ORIENTALE-The brilliant "Or. iental Poppy," with large and flaming flowers, two year.

\section{PENTSTEMON}

BARBATUS TORREYI (Scarlet Beard Tongue) -Close set spikes of small brilliant scarlet flowers; July and August. The flower stems shoot straight up from the ground three to four feet, and are brightly attractive as they nod and sway above surrounding plantings. 10c each; $\$ 1.00$ per dozen.

\section{HARDY PHLOX}

No class of hardy plants is more desirable than the Perennial Phlox. They will thrive in any position and can be used to advantage in the hardy border, in large groups on the lawn or planted in front of belts of shrubbery, where by judicious pinching back and removing faded flowers, a constant succession of bloom may be had until frost. Except the dwarf species, all Hardy Phlox are admirably adapted to cutting. We offer a select list of strong field grown roots. ATHIS-Tall, bright salmon-pink, violet eye. BRIDESMAID-Blush red eye.

EIFFEL TOWER - A most beautiful shade of shell pink. The most popular Phlox grown.

MAD. P. IAANGIER-Brilliant crimson. This is one of the richest colored and most striking red Phloxes known; for years our best seller.

PEACH BLOSSOM-Peach blossom pink.

PANTHEON-The peerless pink. Extra large, always flat flowers of salmon rose.

RICHARD WALLACE-Violet-eyed, white.

H. P. STRUTHERS-Rosy carmine with claretred eye. Also over 20 other leading sorts.

\section{STATICE}

IATIFOLIA (Sea Pink)-A native of Russia and exceedingly hardy. The plant grows about a foot high, has broad luxuriant foliage and slightly recurved spikes of lilac flowers in midsummer.

\section{SHASTA DAISY}

Large flowered improved hybrids. STOKESIA (Corn Flower)

CYANEA-A most charming and beautiful plant. Grows from 18 to 24 inches high, bearing freely from early in June until October its hand. some cornflower-like blossoms, which measure from four to five inches across. Lavender blue. ALBA-White with pink tinge.

\section{VERONICA}

AMETHYSTINA (Speedwell)-Amethyst blue flowers in May and June.

INCANA-Bright silvery foliage, with spikes of amethyst-blue flowers; July and August, one foot.

\section{YUCCA (Adam's Needle)}

FILAIMENTOSA-A stately foliage and flowering plant equally imposing in solitary or group plantings, always conspicuous. The broad. sword-like foliage is evergreen; while mid-summer shows great erect branching stems bearing a showy display of pendant. creamy-white bells.

\section{BULBS FOR SPRING PLANTING}

CANNAS-Best French, 10c each; $\$ 1$ per doz. CAIADIUMS (Elephant Ear)-20c each; $\$ 2.00$ per 12.

DAHLIAS-In a variety of colors, $15 \mathrm{c}$ each; $\$ 1.50$ per 12 .

GLADIOLUS-These are among the most showy and brilliant of all bulbous plants. All colors and combinations. Our stock is of Groff's Hy. brid seedlings, 25c per doz; $\$ 1.50$ per 100 . Named varieties, 60c per $12 ; \$ 4.00$ per 100 .

HEMEROCALLIS, or Lemon Lily-Yellow, $10 \mathrm{c}$ each; $\$ 1.00$ per doz.

TIGER LILY-Spotted, red, orange and black, $15 \mathrm{c}$ each.

LILIES-We carry some of the rare sorts as the Gold Band Japanese Lily, Speciosum Album and Rubrum, etc. 25c each; $\$ 2.50$ per doz.

TUBEROSES-The Pearl, the new more dwarf sort. 35c per dozen.

\section{BULBS FOR FALL PLANTING}

We carry a complete stock of fall bulbs such as Hyacinths, Tulips, Crocus, Narcissus, etc., imported from Holland each fall. These must be planted in the fall to succeed. Prices on application in fall.

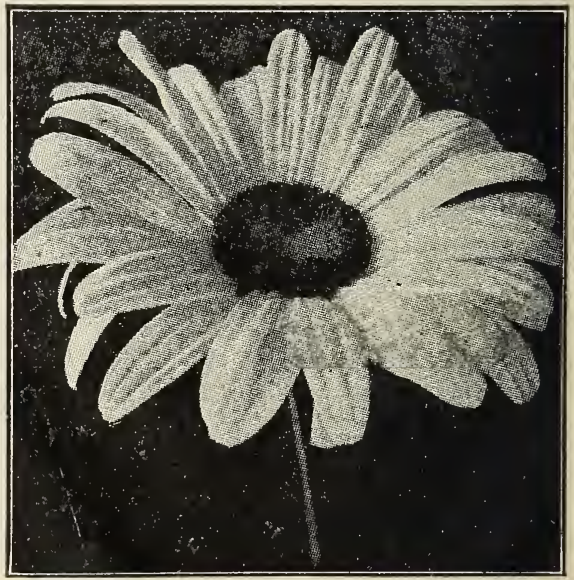

THE CHASTA DAISY 


\section{The Peonies are Desirable}

PEONY (Single Blush)-In our estimation this is the most beautiful and satisfactory peony we have ever seen. The original plant obtained 40 years ago from a new unknown source, is still producing an abundant crop of flowers each season. We have never seen the same variety in other nurseries and have been entirely unable to obtain the same thing anywhere else, although we have made numerous attempts. We have a limited amount of nice plants propagated from our clump now ready for sale. Wherever we have sold any in the last few years we have received the high. est words of praise for it. Flowers large, delicate blush when it first opens, fading to white in a few days. Single, with large yellow center, giving it the appearance of a large water lily. Sweet scented. Blooms early and as all buds do not come out at the same time it is in bloom for a longer period than most peonies. Blooms young, almost invariably the first season, and this is true usually even when planted in the Spring. Plant strong and healthy. 50 cents each.

Ontario, Canada, June 12, 1915

I want to get some more peonies, the ones I got from you have done so well. The SINGLE BLUSH I got from you three years ago has over 60 blooms on it now (it had two fine blooms the first season) and is much admired by everyone. I had some of the Dahlias got from you at the Flower Show in Sarnia last Fall and people were raving about them. So many thought they were some new kind of Chrysanthemums. The FLORADORA is the best bloomer of all I ever saw.

MISS M. M'GLASHAN.

The following are our most popular sorts, but we have a number of others in smaller supply. 25 c each; $\$ 2.50$ per 12 ; except where noted.

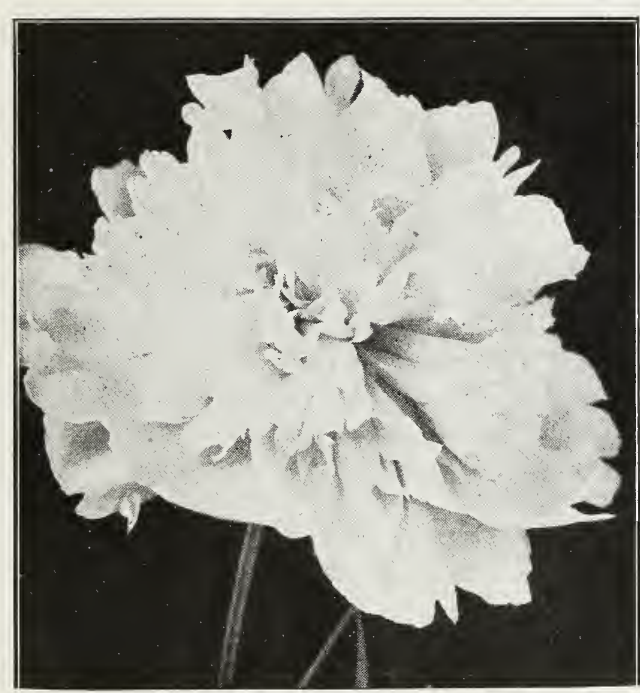

Festiva Maxima

\section{THIERS-Rose, shaded purple.}

MODESTE. GUERIN-Brilliant carmine-rose, with a high and stiff center full of rosy-pink petals.

MONS. JULES ELIE-Extra choice variety; massive, double, chrysanthemum shaped; superb, clear pure pink. $50 \mathrm{c}$ each.

OFFICINALIS ROSEA (fl. pl.)-Beautiful, clear pink; double; extra early and fine, $35 \mathrm{c}$.

OFFICINALIS RUBRA PLENO-Rich, deep crimson; very early and one of the brightest of all dark colored varieties.

ROSE D'AMOUR-Soft flesh pink, very fresh color. Extra. Large flower. $35 \mathrm{c}$.

RUBRA TRIUMPHANS-Very large bloom, brilliant crimson.

SOLFATARE-Large, compact; sulphur white, crown ripe, borders milky white. Extra.

SOUVENIR DE L'EXPOSITION UNIVE'RSELLE-Very large full blooms of exceptional fine form; color clear cherry red with silvery reflex.

TENUIFOLIA OR FRINGE LEAF-A beautiful novelty with delicate fern-like foliage. Flowers the brightest fiery red, produced early. $50 \mathrm{c}$.

TRICOLOR GRANDIFLORA-Large bloom, color soft rose with salmon center. $40 \mathrm{c}$.
BERLIOZ-Enormous full globular imbricated bloom, bright currant red center tinted rose and shaded with amaranth. Very late bloomer.

CHINENSIS ALBA-White, outer petals rosy. Red stamens.

COURONNE D'OR-Late white, showing gold reflections and slight carmine tips. 50c.

FESTIVA MAXIMA-About the largest and undoubtedly the most popular Peony of them all. High built flowers borne on long, stiff stems; the purest white, inner petals slightly tipped carmine. $50 \mathrm{c}$.

FLORAL TREASURE-Clear, delicate pink; very double and fragrant. $40 \mathrm{c}$.

HUMEI-Pure, bright, deep rose; vigorous grower; one of the best late blooming varieties.

ISABELLA KARLITZKY-Delicate rose; very large and full.

L'ECLATANT-Broad, full flowers of purplish crimson.

MARIE LEMOINE (Calot)-Dwarf, extra late, and very scarce. White, faintly tinged chamois.

THE BENTON REVIEW SHOP, FOTLER, IND.

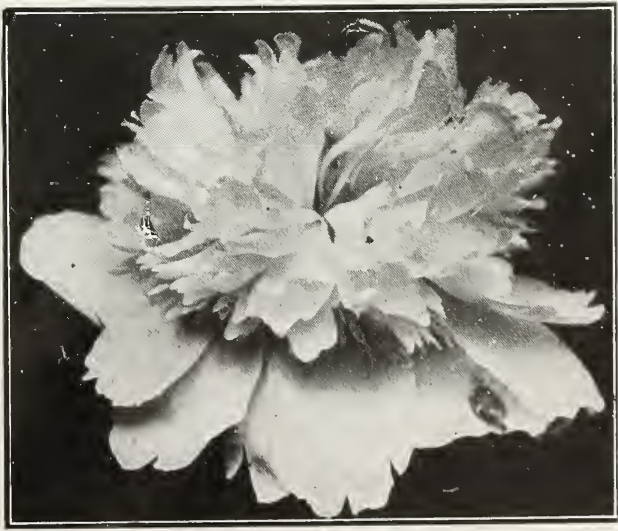

Mons. Jules Elle 


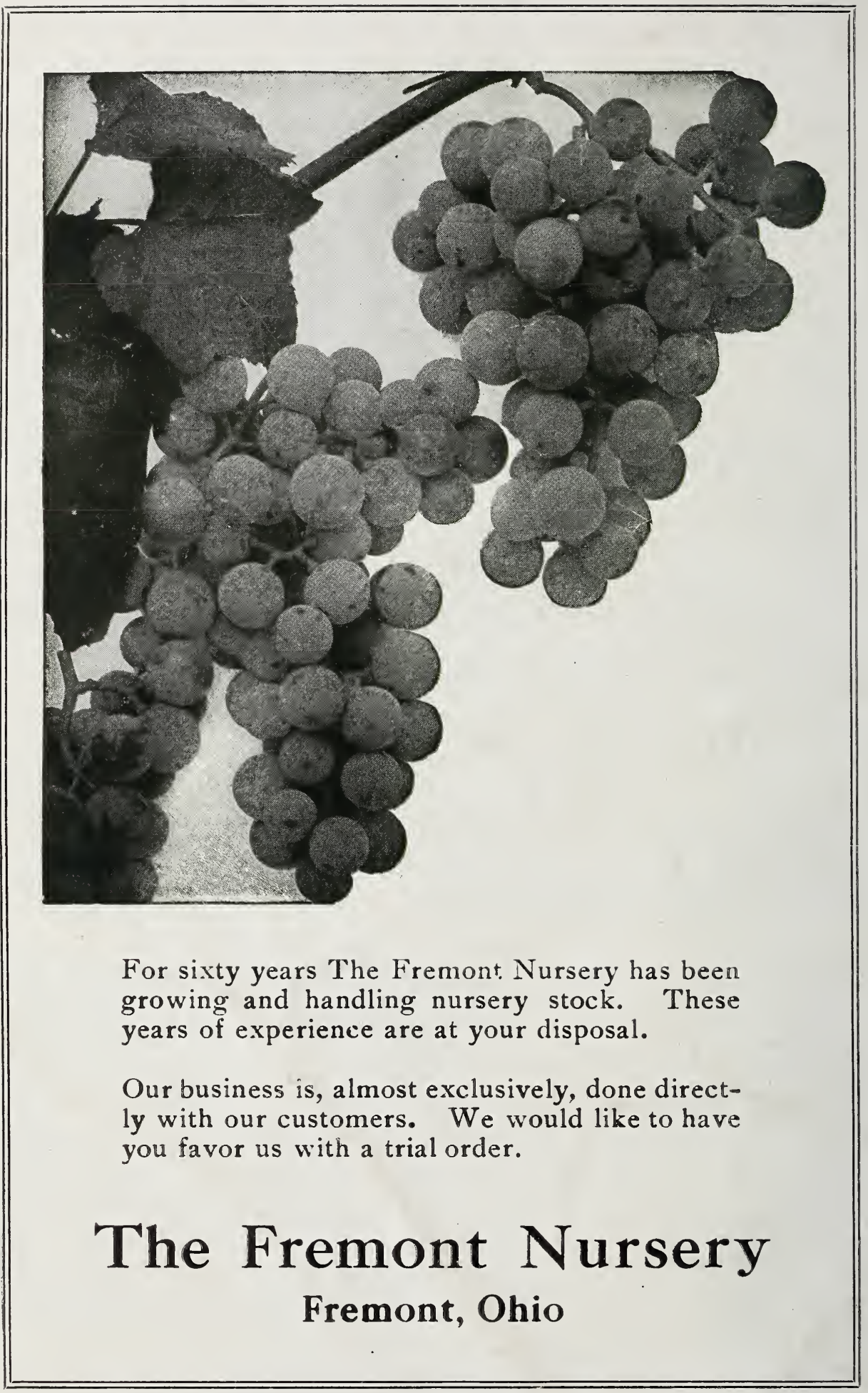

